\title{
Providing a Model for Exposing Corporate Sustainability and Evaluating the effect of Factors Related to Signaling Theory and Stakeholders on Reporting of this Information
}

\author{
Mozaffar Pourkhani zakeleh bari \\ PHD student of accounting, Central Tehran Branch, Islamic Azad \\ University, Tehran(mozaffar_pourkhani@yahoo.com)
}

\author{
Azita Jahanshad * \\ associate professor, Department of Accounting, Central Tehran Branch, \\ Islamic Azad University, Tehran(Corresponding Author), \\ az_jahanshad@yahoo.com
}

Farzaneh Heidarpoor

associate professor, Department of Accounting, Central Tehran Branch, Islamic Azad University, Tehran (fheidarpoor@yahoo.com)

\begin{abstract}
:
Given the expansion of business activities in the world and the potential for sustainability in creating opportunities, the category of sustainability has become one of the first goals of countries and companies. But in Iran, less attention has been paid to this issue. Therefore, the purpose of this study is first to provide a model for disclosing corporate sustainability and then the impact of factors related to signaling theory and stakeholders on corporate sustainability reporting.Therefore, in order to achieve the pattern of corporate sustainability disclosure (qualitative part), purposeful sampling method and Delphi method were used by 28 experts, and to test other hypotheses (quantitative part of the research), 117 companies listed on the Tehran Stock Exchange that were used by the Systematic elimination have been studied in the period 2011-2018. To test the hypotheses, panel regression models were used. Delphi test findings and Kendall coefficient show that according to the experts, out of 169 components studied, 80 components are included in the corporate sustainability disclosure model.Among the factors related to signaling theory, firm performance has a direct impact on the overall corporate sustainability index, disclosure from an economic and environmental point of view. In addition, the percentage of firm sustainability costs has a direct impact on the overall corporate sustainability index, public,
\end{abstract}


Semiannually journal of Value \& Behavioral Accounting dof $10.52547 / \mathrm{aapc} .5 .10 .385$

environmental and social disclosure. Also, among the factors related to stakeholder theory, government ownership has a direct impact on the overall index and all aspects of corporate sustainability, and board ownership has a direct impact on the overall corporate sustainability index, public, economic and environmental disclosure. The findings of this study show the importance of requiring non-financial information disclosure for legislators and standardizers. The proposed model also improves stakeholder awareness of these aspects

\section{Copyrights}

This license only allowing others to download your works and share them with others as long as they credit you, but they can't change them in any way or use them commercial. 


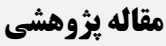

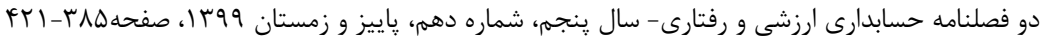

\section{ارائه الكويى براى افشاء اطلاعات بايدارى شركتى و ارزيابى اثرعوامل مرتبط با تئورى علامتدهى و ذينفعان بر تَزارشكَى اين اطلاعات

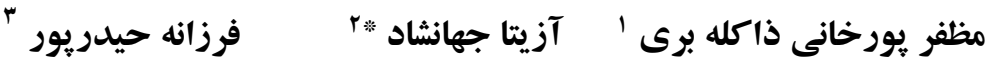

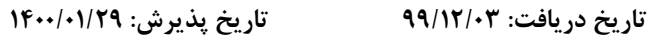

\begin{abstract}
جكيده
با توجه به كسترش فعاليتهاى تجارى در جهان و پتانسيل بايدارى در خلق فرصتها، مقوله

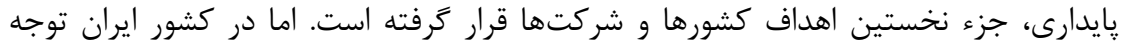

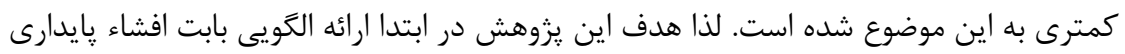

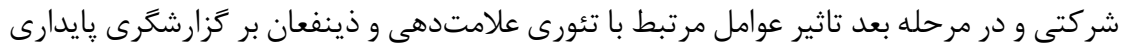

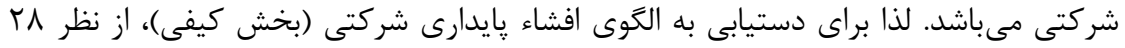

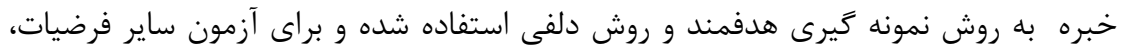

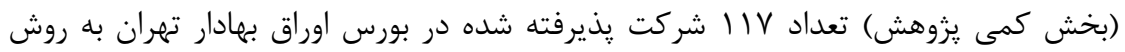

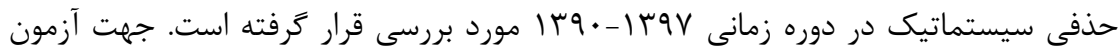

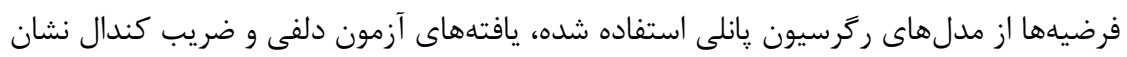

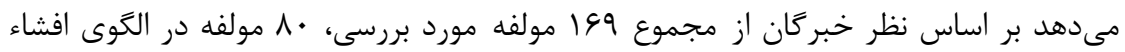

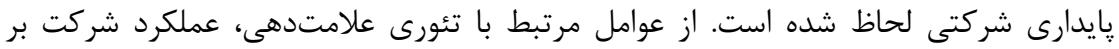

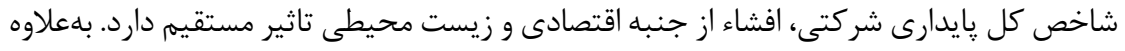

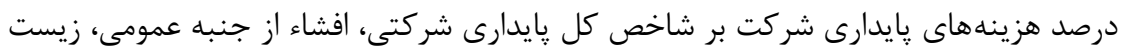

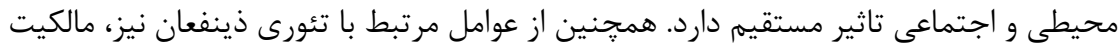

$$
\begin{aligned}
& \text { 'دانشجوى دكترى حسابدارى، واحد تهران مركزى، دانشكاه آزاد اسلامى، تهران، ايران. } \\
& \text { (mozaffar_pourkhani@yahoo.com) } \\
& \text { 'دانشياركروه حسابدارى، واحد تهران مركزى، دانشگاه آزاد اسلامى، تهران، ايران (نويسنده مسئول)، } \\
& \text { az_jahanshad@yahoo.com }
\end{aligned}
$$

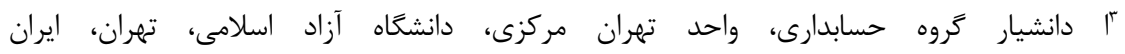


دولتى بر شاخص كل و تمامى جنبههاى بايدارى شركتى تاثير مستقيم دارد و مالكيت اعضاى

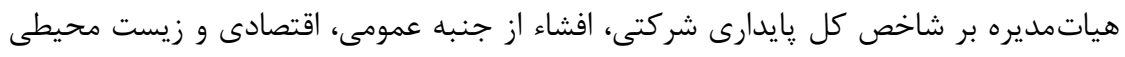

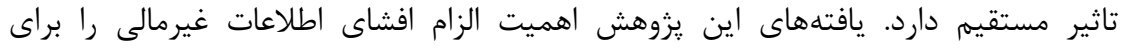

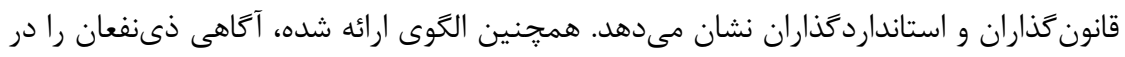
مورد جنبdهاى مذكور بهبود ميخ بخشد.

كليد وازه ها: عملكرد، درصد هزينهاى يايدارى، مالكيت دولتى، مالكيت اعضاى هياتمديره،

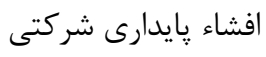


ذينفعان مختلف انتظارات متفاوتى از يك شركت دارند و بنابراين نقشهاى متفاوتى در

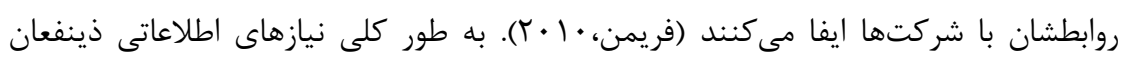

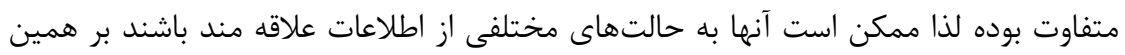

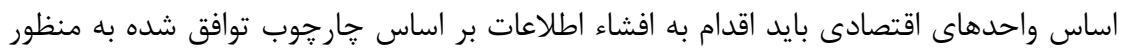

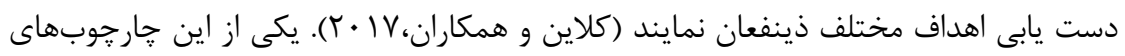

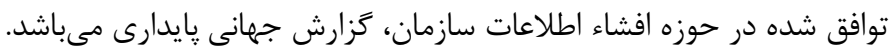

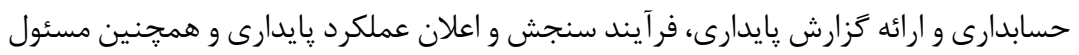

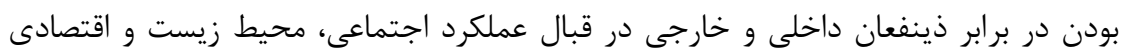

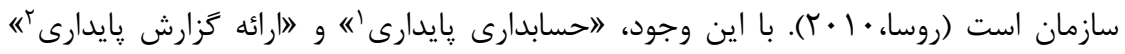

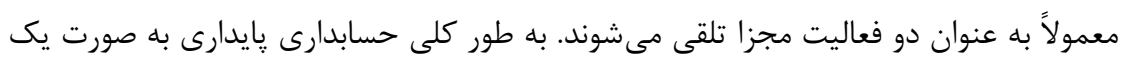

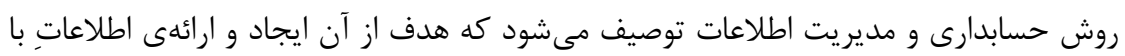

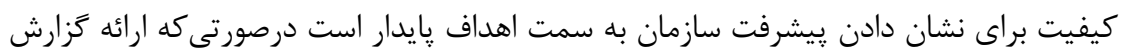

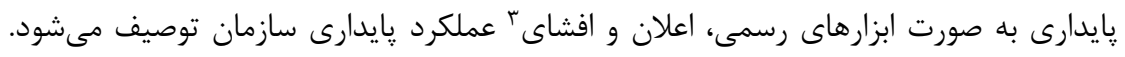

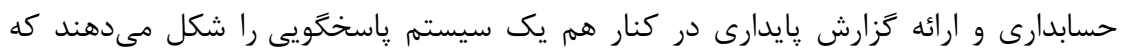

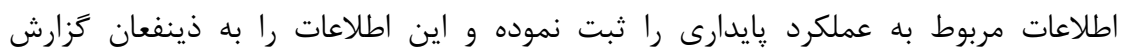

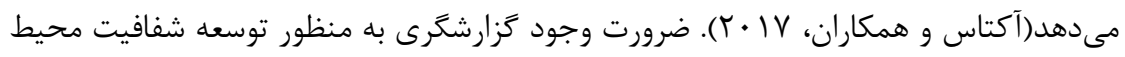

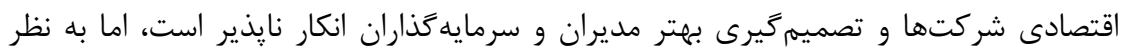

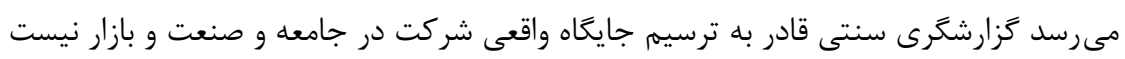

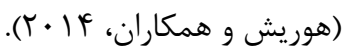

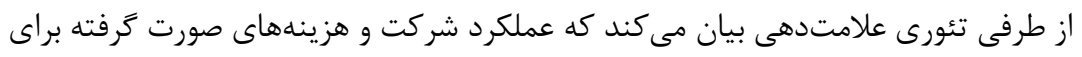

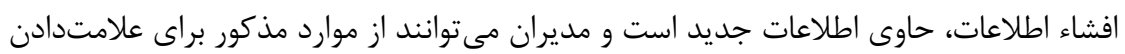

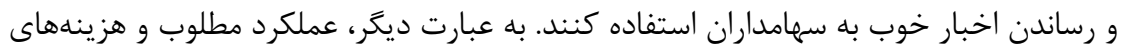

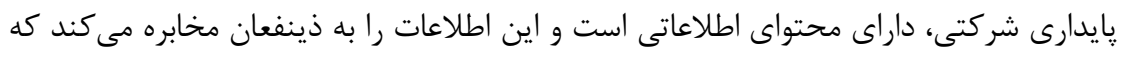

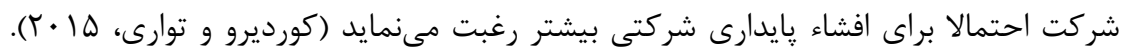

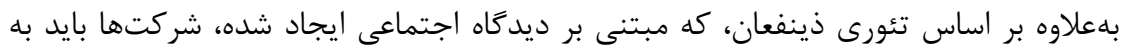

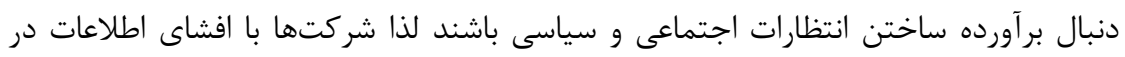

1 Sustainability accounting

2 Sustainability report provide

3 disclose 
كزارشهاى سالانه، تأثير مستقيمى در افزايش سطوح اطمينان جامعه مى كذارند و مشروعيت

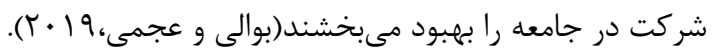

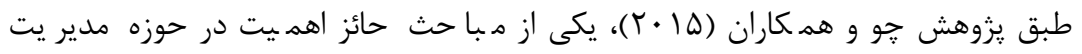

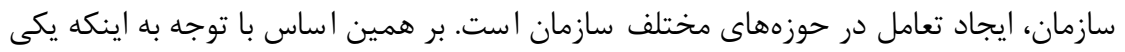

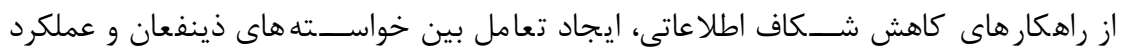

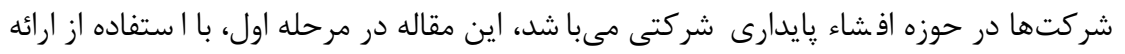

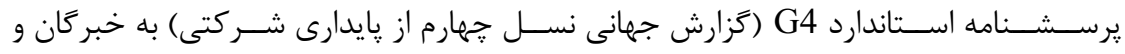

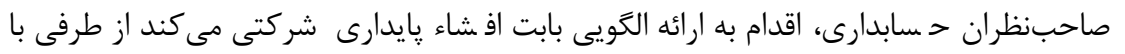

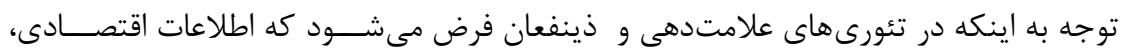

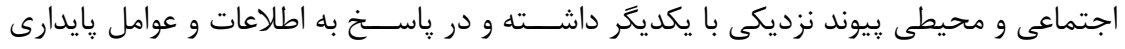

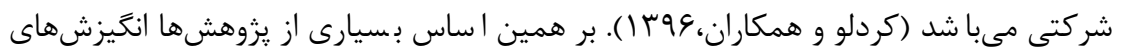

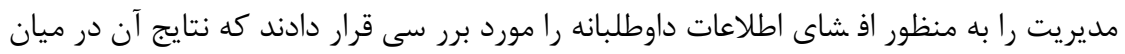

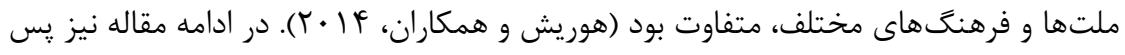

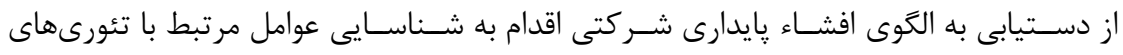

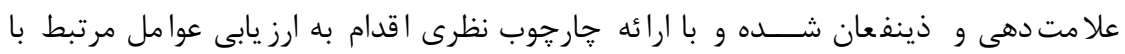

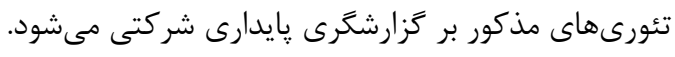

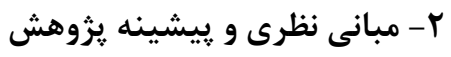

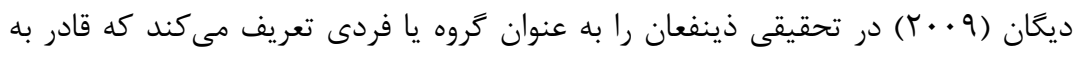

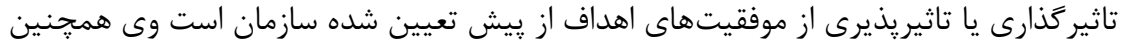

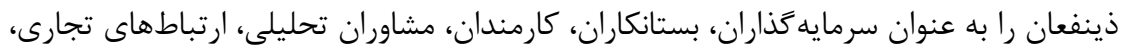

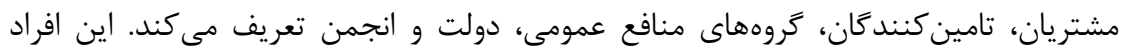

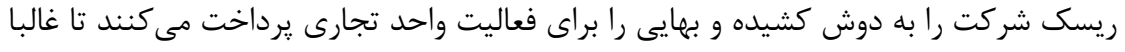

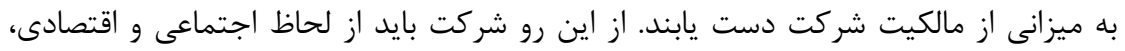

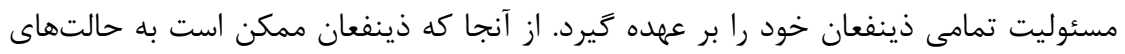

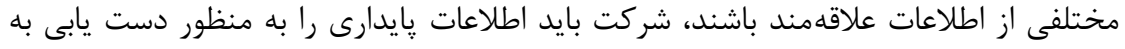

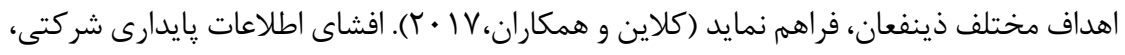

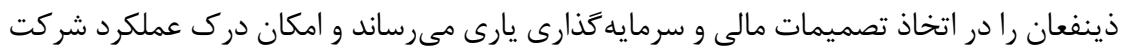

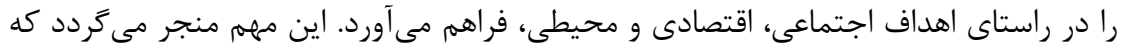

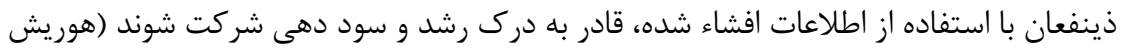




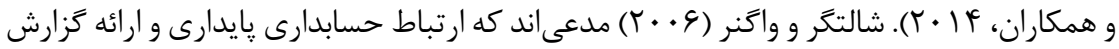

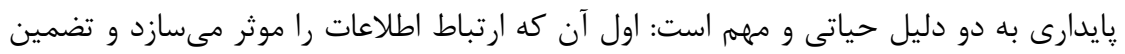

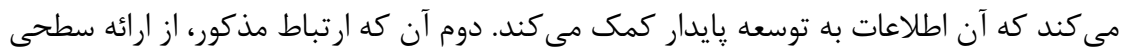

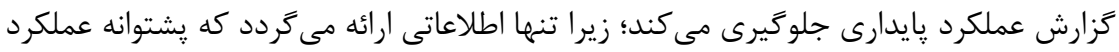

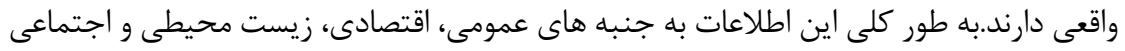

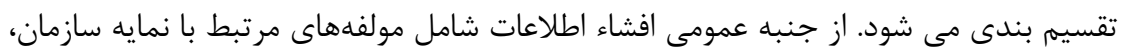

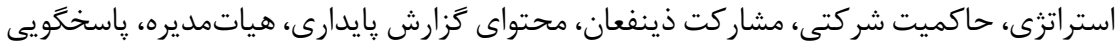

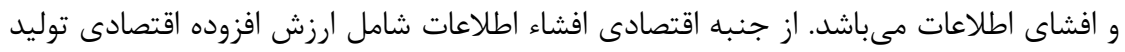

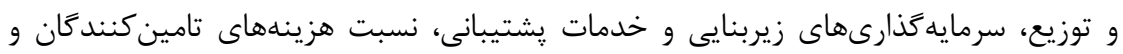

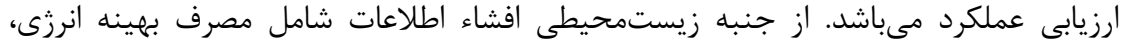

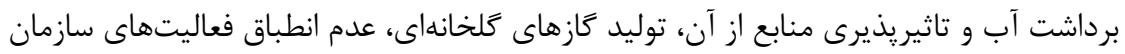

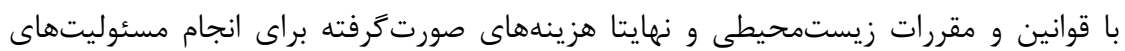

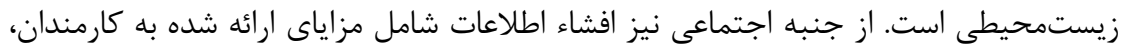

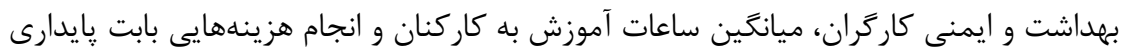

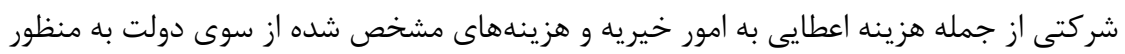

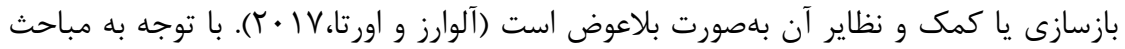

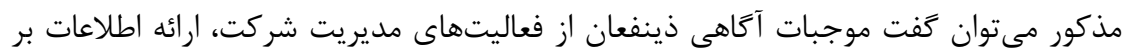

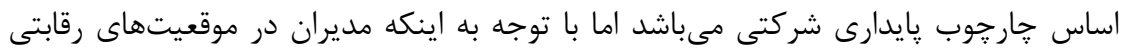

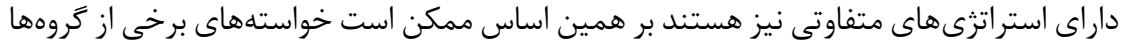

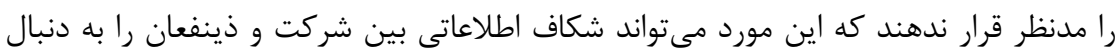

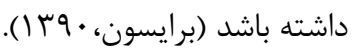
طبق تئورى علامتدهى'، شركتهاى با سطوح بالاى افشاى داوطلبانه نسبت به شركتهاى

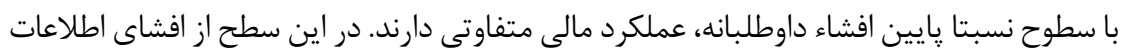

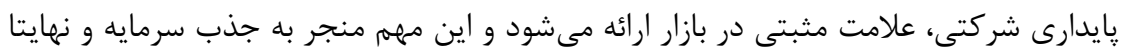

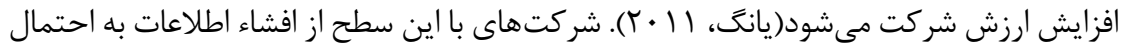

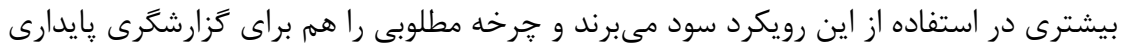

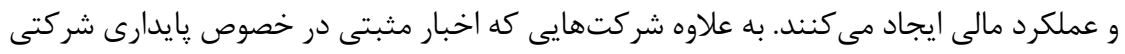

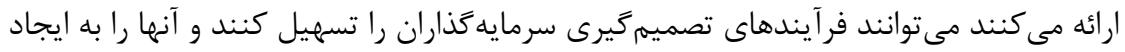

${ }^{1}$ signaling Theory 
اعتماد به واحد اقتصادى و مديريت تشويق كنند. مديريت نيز براى جبران اين اعتماد در راستاى

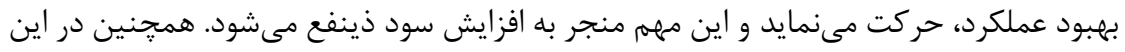

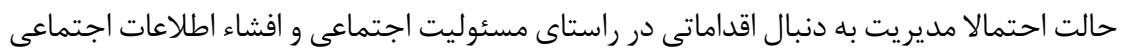

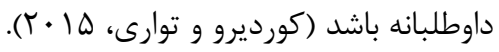

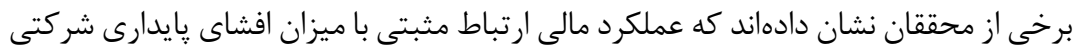

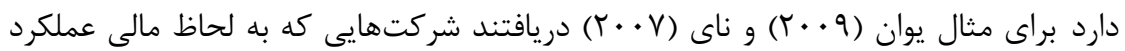

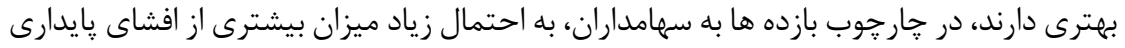

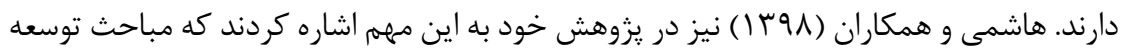

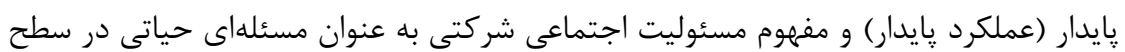

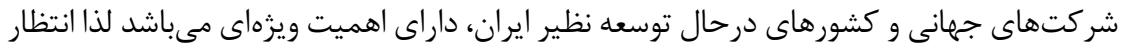

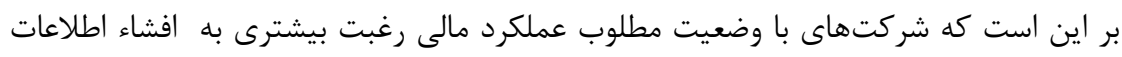

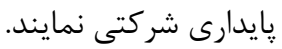

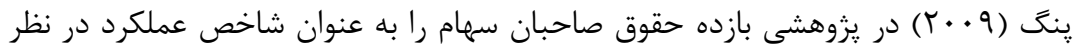

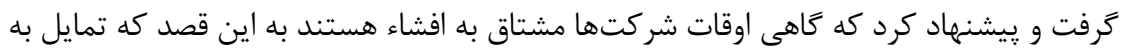

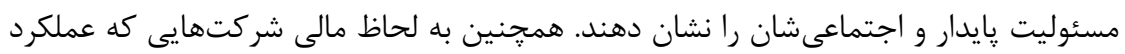

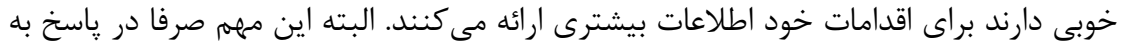

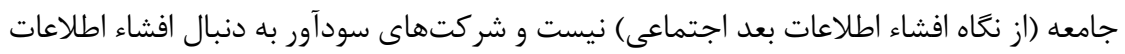
اقتصادى و زيست محيطى هم هستند. از طرفى هزينه پايدارى شركتى ' نيز به عنوان نوعى از هزينه افشاء اطلاعات در نظر كرفته

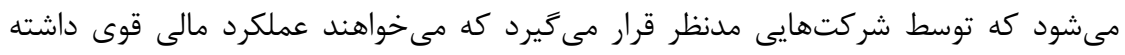

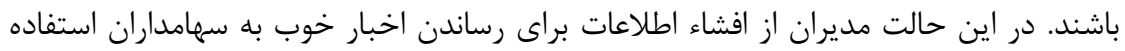

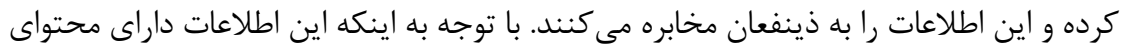

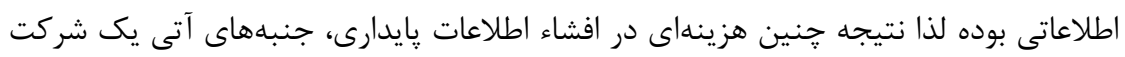

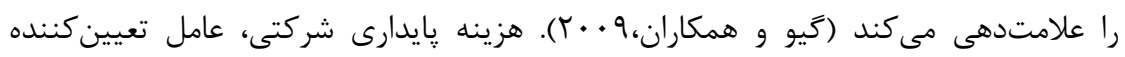

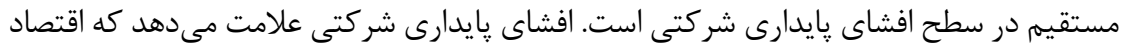

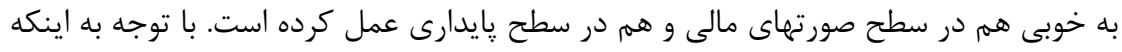

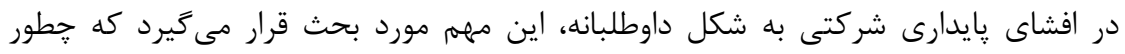

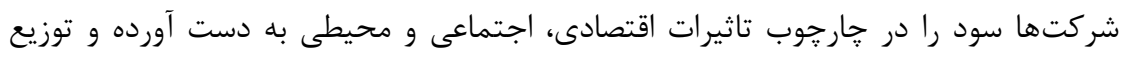

1 corporate sustainability 
एव) دكتر جهانشاد و همكاران، ارائه الكَيى براى افشاء اطلاعات پايدارى شركتى و ارزيابى اثرعوامل ...

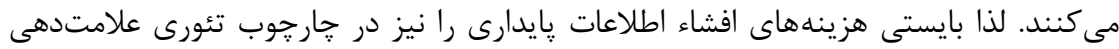

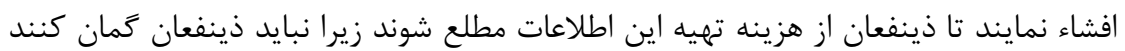

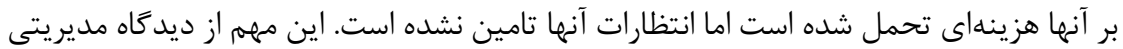
منجر به اين قضيه مىشود كه ذينفعان براى اخذ اطلاعات پايدارى شركتى، انتظارات منطقى تانى داشته باشند و هزينه تهيه اطلاعات را هم در راستاى نيازهاى اطلاعاتى خود لحاظ نمايند لايس

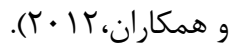

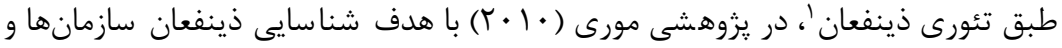

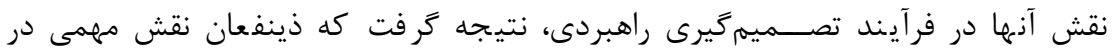

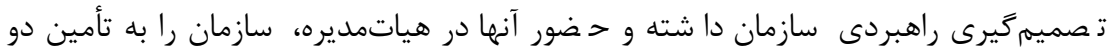

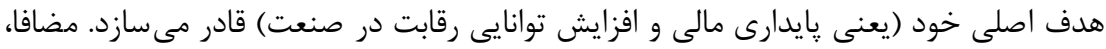

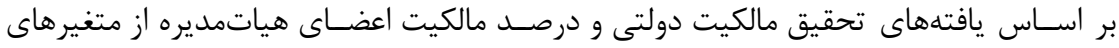

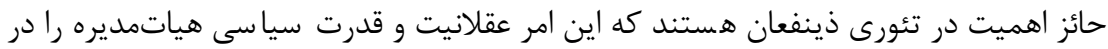
فرآيند تصميمكيرى راهبردى در بيى داشته و به تصميمات كارآمد و عملكرد (از جمله عملكرد

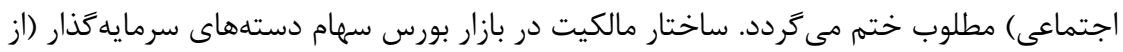

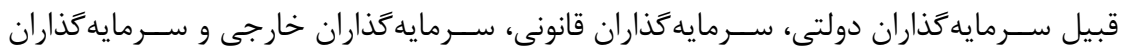
عمومى داخلى) را ايجاد مى كند. طبق تئورى ذينفعان، سطوح مختلف از ساختار و انواع مالكيت دانيت

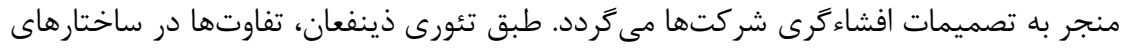

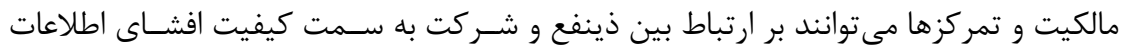

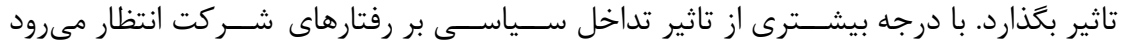

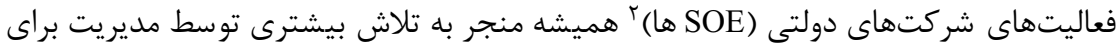

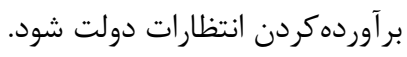

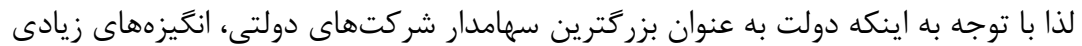

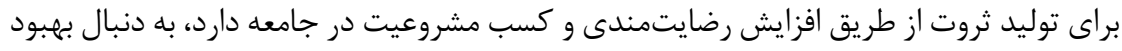

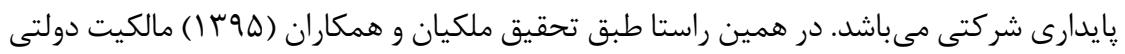

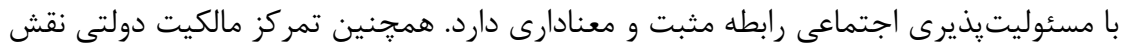
مثبتى در افشاى اطلاعات مسئوليت اجتماعى شركتها (يكى از ابعاد بإيدارى شركتى دئى ايفا

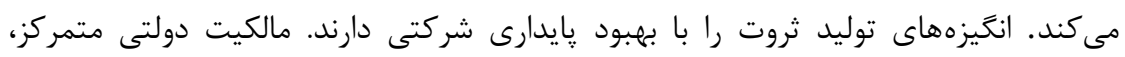

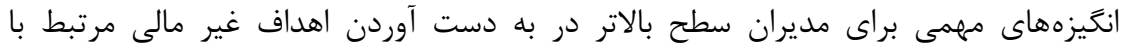

${ }^{1}$ stakeholders Theory

${ }^{2}$ State owned enterprise 


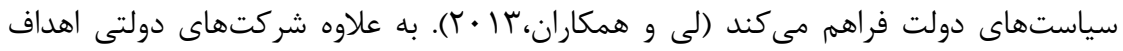

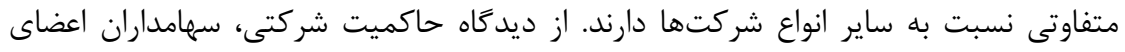

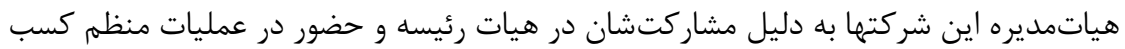

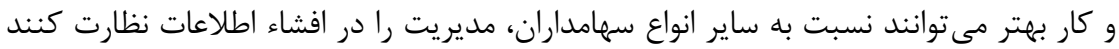

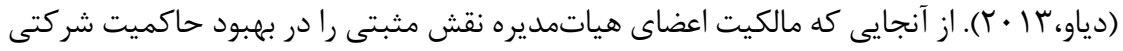

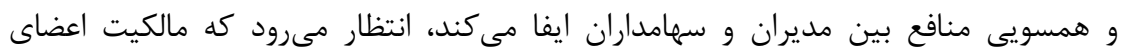

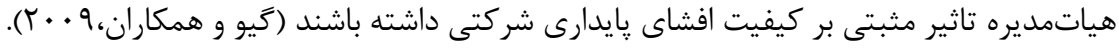

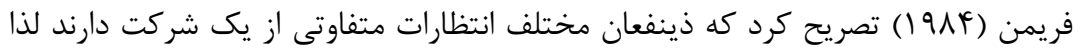

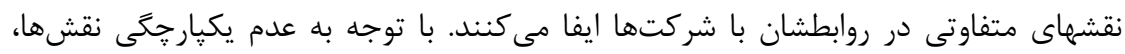

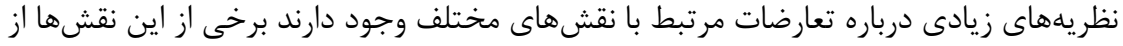

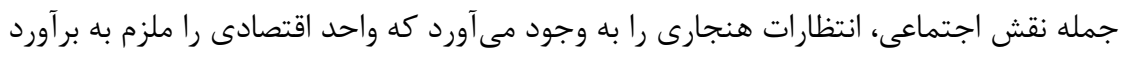

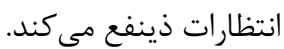

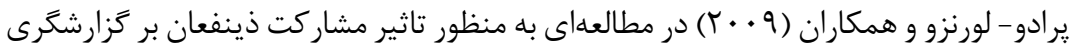

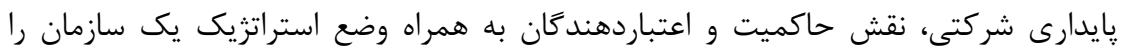

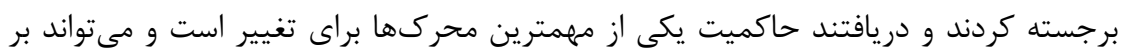

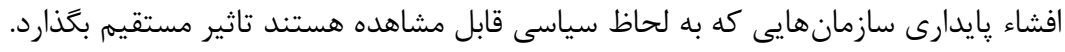

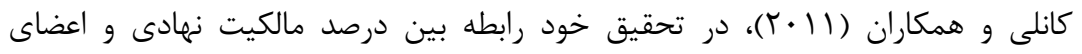

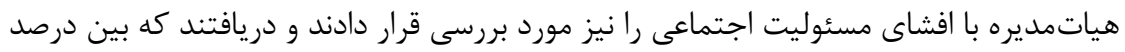
مالكيت نهادى و اعضاى هياتمديره با افشاى مسئوليت اجتماعى رابطه مثبت و معنى دارى وجودي دورد

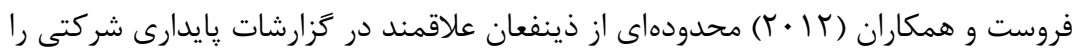

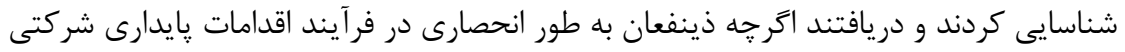

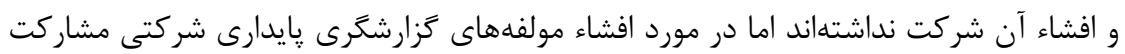
قابل ملاحظهاى داشتهاند.

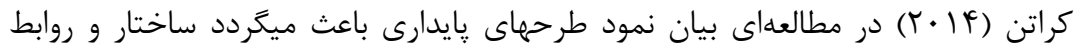

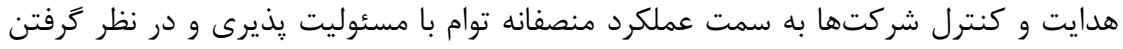

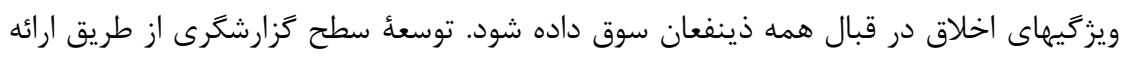

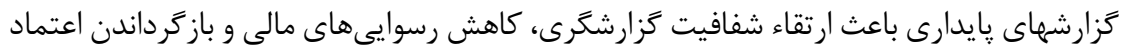

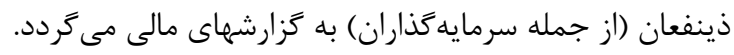


بيكساو (1) (1) به بررسى سودآورى، مالكيت دولتى و كزارشهاى مالياتى با مسئوليت

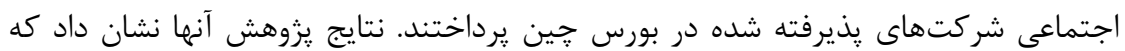

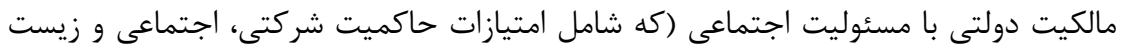

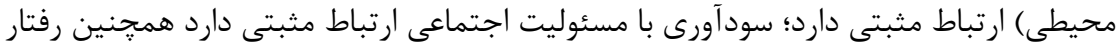

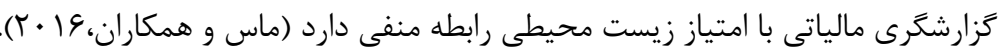

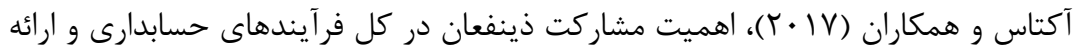
كزارشكرى بايدارى را بررسى كردند و دريافتند كه ذينفعان به مواردى از جمله توسعه طرحهاى

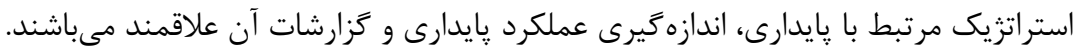

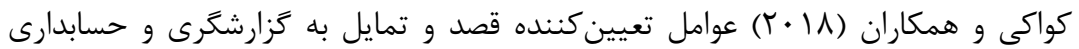

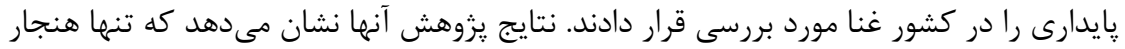

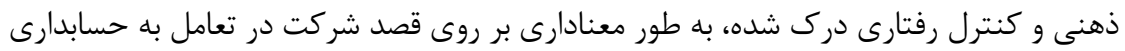

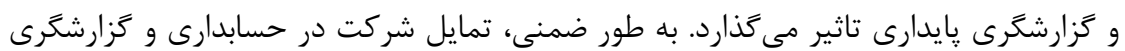

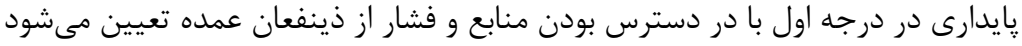

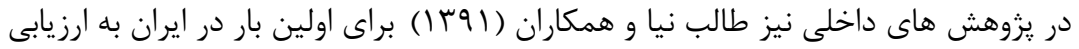

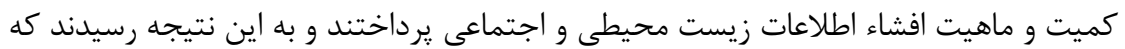
شركتهاى ايرانى ترجيح مى دهند اطلاعات زيست محيطى و اجتماعى را در كزارش هياتمدئ

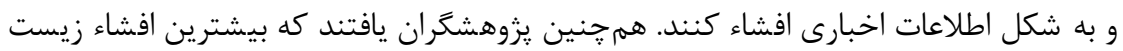

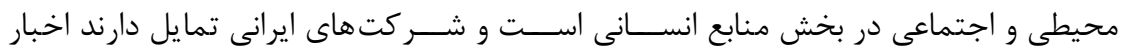
بى طرفانه سيس اخبار خوب را بيشتر از اخبار بد افتشاء كتند.

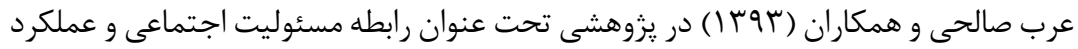

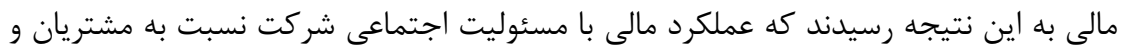
نهادهاى موجود در جامعه ارتباط دارد.

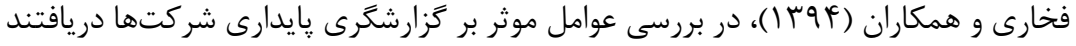

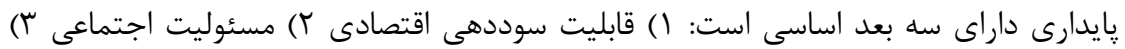

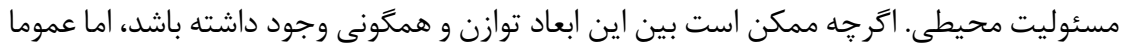

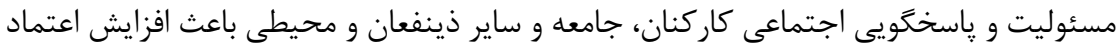

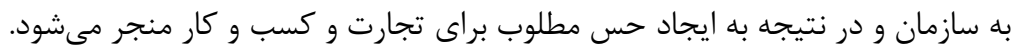
معصومى و همكاران (Y (I I ) در تحقيق خود با عنوان شناسايى متغيرهاى مؤثر بر ميزان

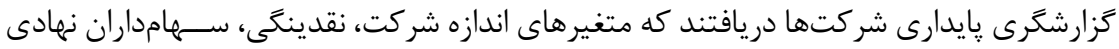

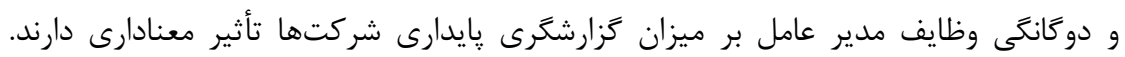


همجنين سه متغير عمر شركت، دارايى نامشهود و استقلال هياتمديره بر ميزان تزارشكَى يايدارى شركتها تأثير معنادارى ندارند.

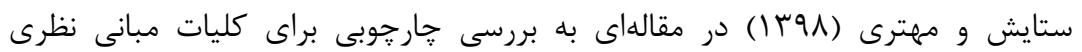

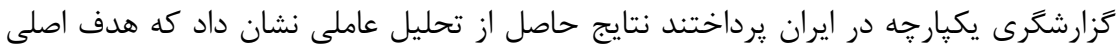

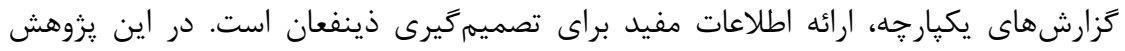
تحليل

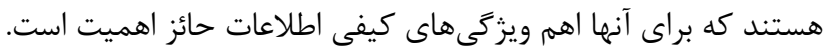

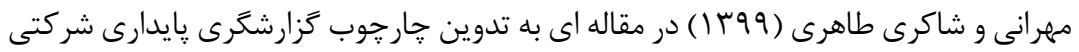

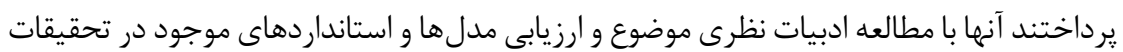
مختلف و در نظر ترفتن شرايط محيطى شركتهاى ايرانى و كسب نظرات خبر كان، مدل اشاعه

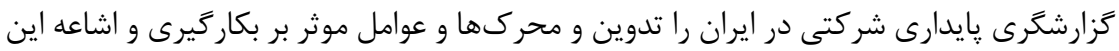

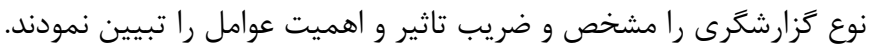

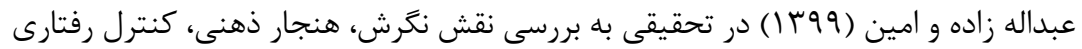

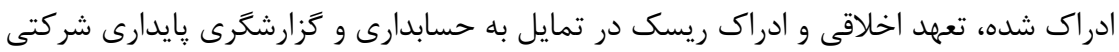

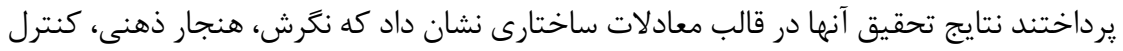
رفتارى ادراكشده، تعهد اخلاقى تاثير مستقيمى بر تمايل به اجراى حسابدارى و كزارشكَرى

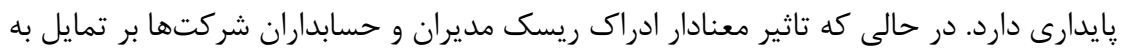

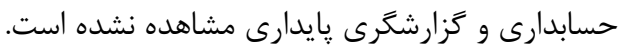

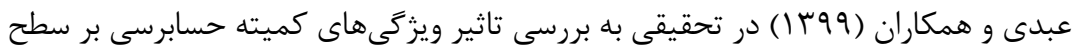

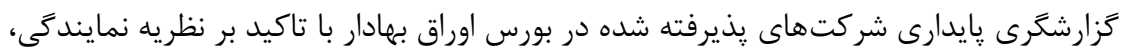

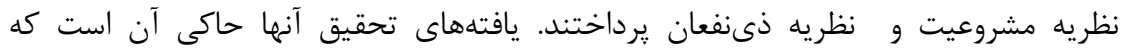
ويزگگ هاى كميته حسابرسى (اندازه، استقلال، تخصص مالى و تنوع جنسيتى

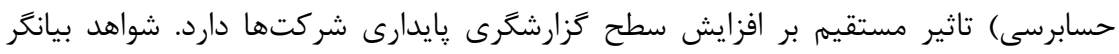

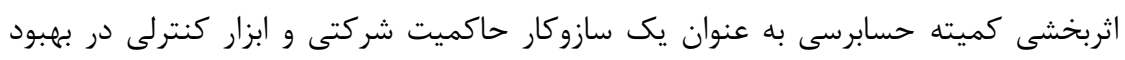
كيفيت كزارشكَى به طور عام و كزارشكرى پايدارى بهصورت خاص به منظور تحقق اهداف

$$
\text { ذى نفعان است. }
$$

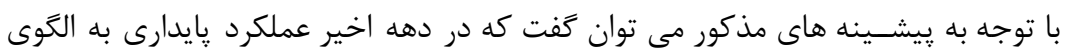

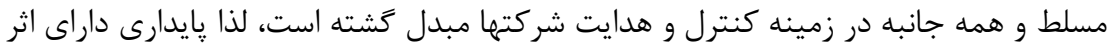
بالقوه بر شركت مى باشد. از طرفى نيز علاقه سرمايه كذاران، منجر به معطوف شدن نظر آندان آنها به

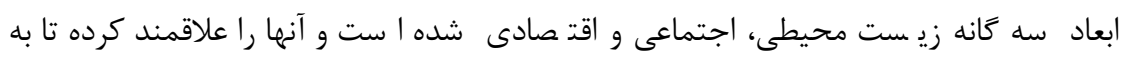


دنبال شـناسـايى عوامل مرتبط با تئورى هاى (علامت دهى و ذينفعان در اين يزوهش) مختلف

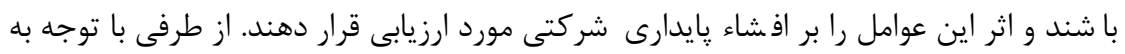

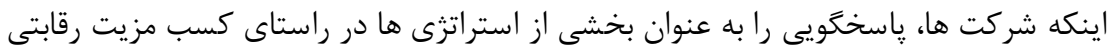

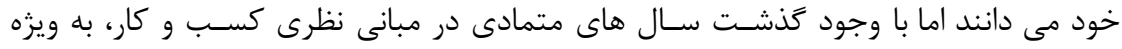

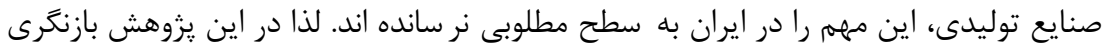

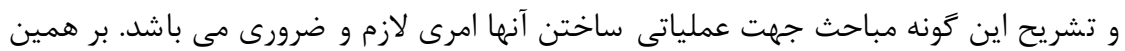

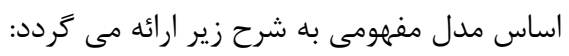

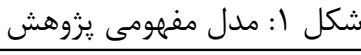

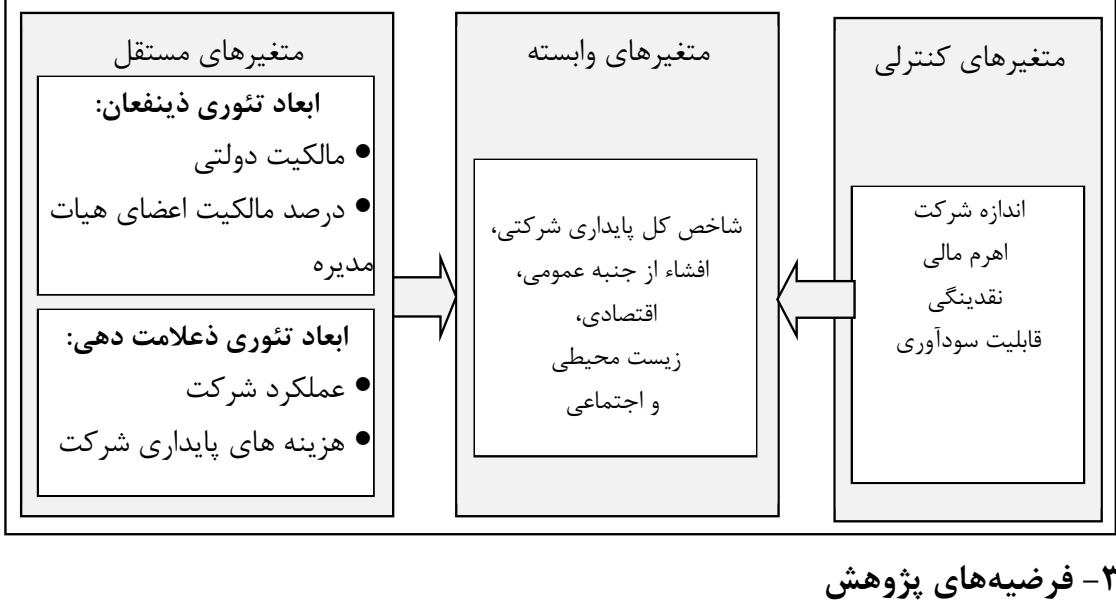

نظريه ذينفعان به اين موضوع اشاره دارد كه فعاليتها و عملكرد پايدار، ارزش بلندمدت شركت

را توسط برآورده ساختن مسئوليت اجتماعى شركت، برآورده ساختن تعهدات زيست محيطى

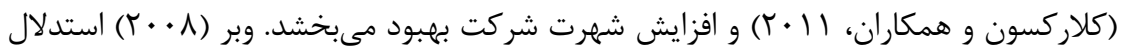
مى كنند كه لحاظ كردن منافع ذينفعان توسط مديريت عامل كليدى در عملكرد و افشاى بايدارى

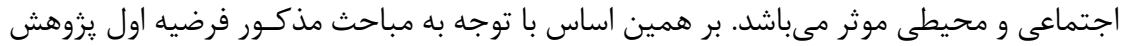

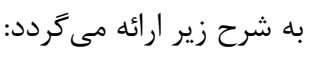

فرضيه ا: گَزارشكَرى مولفه هاى عمومى، اقتصادى، زيست محيطى و اجتماعى در الكَوى بايدارى

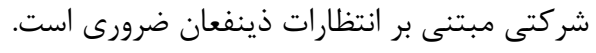

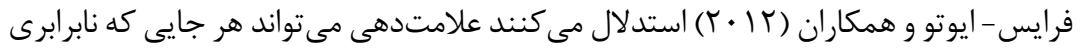

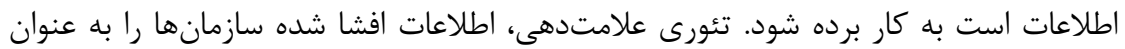

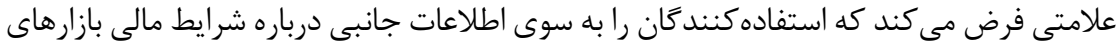


آنها هدايت مى كند، و با منسجم كردن اطلاعات، سرمايه گذاران را در مراحل تصميم گيرىشان

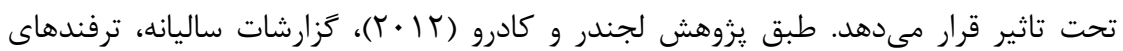

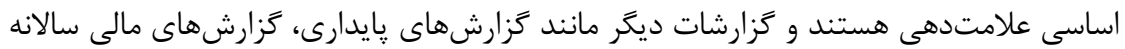

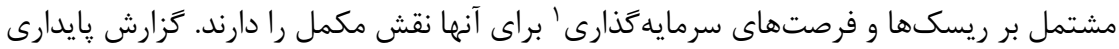

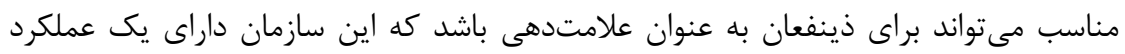

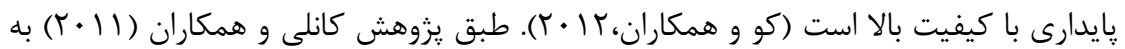

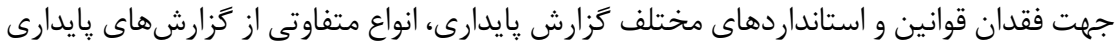

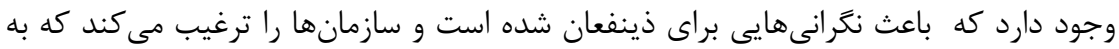

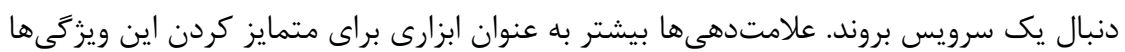

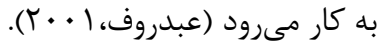

كرى و همكاران (1990) بيان مىنمايند كه بين افشاء اطلاعات و ذينفعان بايستى تعامل وجود داشته باشد به طور كلى ذينفعان انتظار دارند كه اطلاعات بيشترى درباره واحدانداء إنداء تجارى

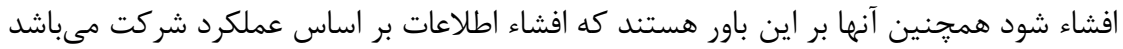

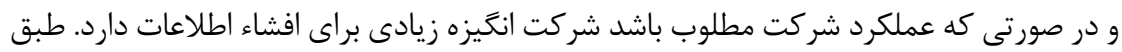

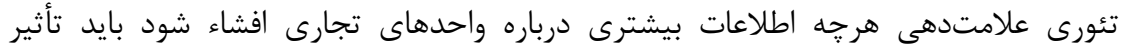
مستقيمى بر عملكرد شركتها داشته باشد افشاى بيشتر منجر به كاهش اهميت مشكل عدام

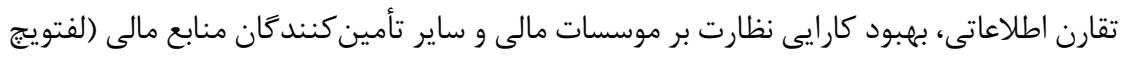

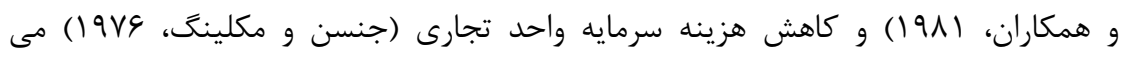

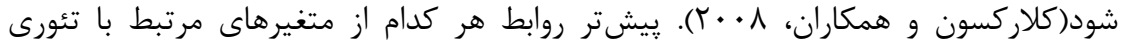

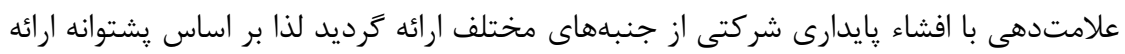

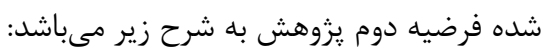

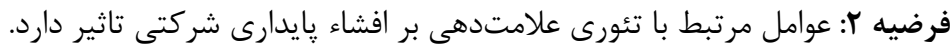

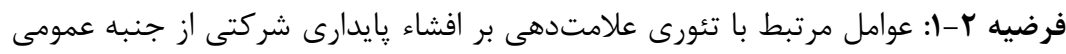

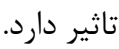
فرضيه r-r- عوامل مرتبط با تئورى علامتدهى بر افشاء بايدارى شركتى از جنبه اقتصادى

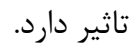
فرضيه r-r-r: عوامل مرتبط با تئورى علامتدهى بر افشاء پايدارى شركتى از جنبه زيست محيطى تاثير دارد.

${ }^{1}$ Standalone environmental sustainability reports 
فرضيه r-f أ عوامل مرتبط با تئورى علامتدهى بر افشاء يايدارى شركتى از جنبه اجتماعى

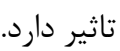

نظريه ذينفعان كه مبتنى بر ديدكاه اجتماعى ايجاد شده، به اين موضوع اشاره دارد كه شركت

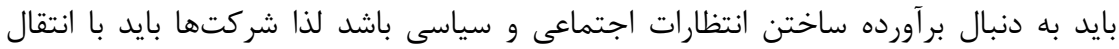

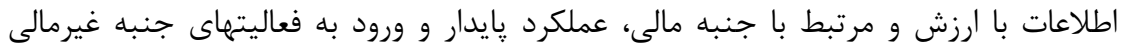

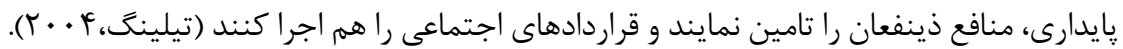
بر اساس نظريه مذكور، عملكرد يايدارى شركتى، مطلوب تمام ذينفعان، شامل مشتريان، جامعها

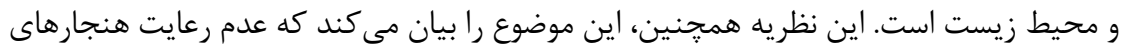

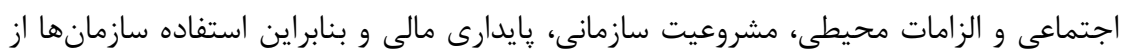

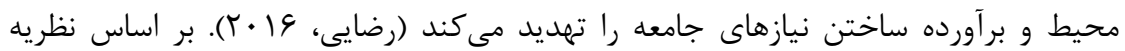

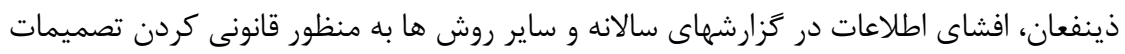

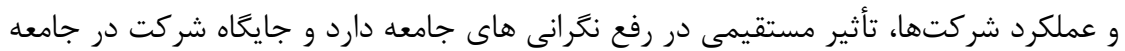

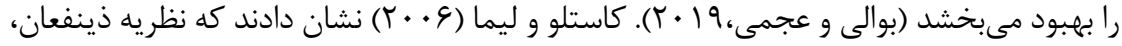

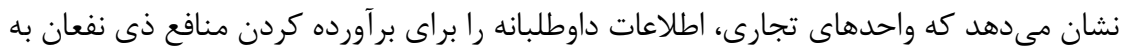

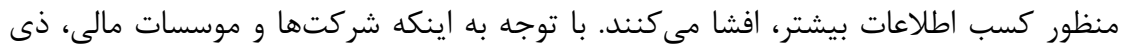
نفعان متنوع و فراوانى دارند و ذى نفعان آنها از ساير بخشهاى اقتصادى گسترده تر هستند، از ازئ

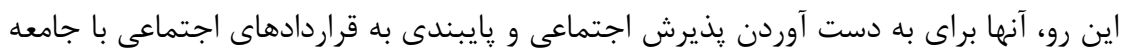

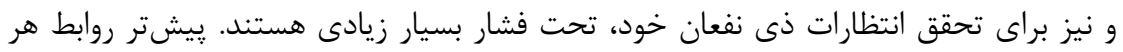

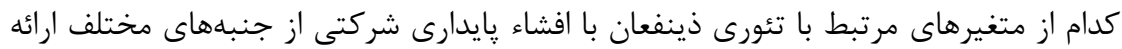

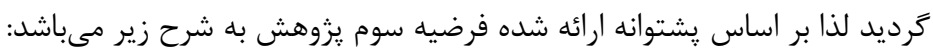

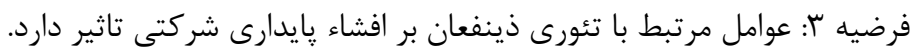

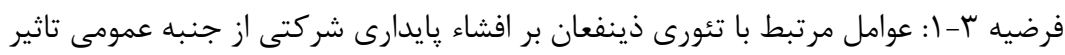

فرضيه r-r: عوامل مرتبط با تئورى ذينفعان بر افشاء پايدارى شركتى از جنبه اقتصادى

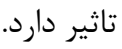
فرضيه س-rّ: عوامل مرتبط با تئورى ذينفعان بر افشاء پإيدارى شركتى از جنبه زيست محيطى تاثير دارد.

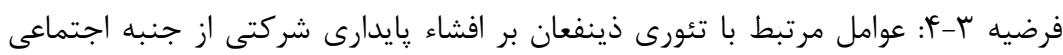

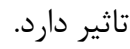




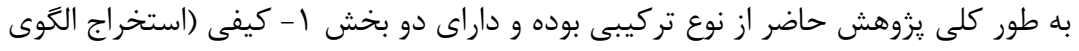

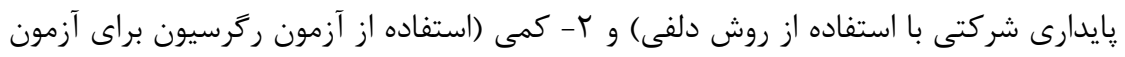

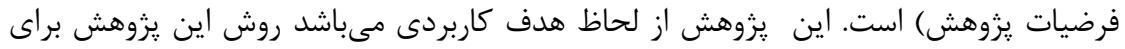

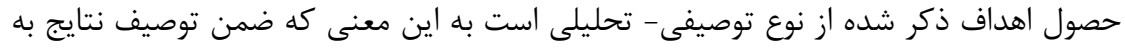

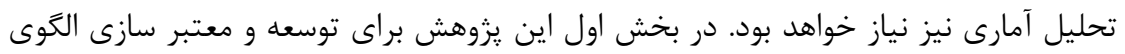

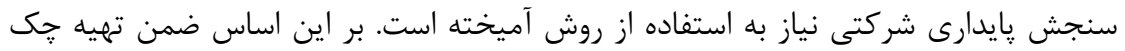

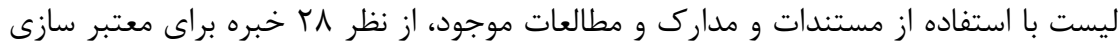

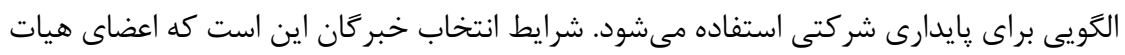

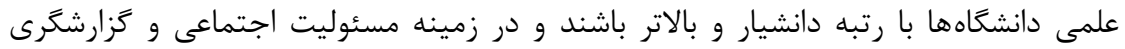

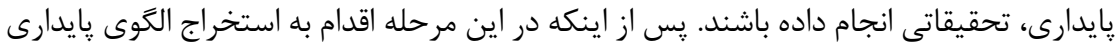

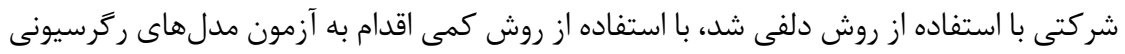

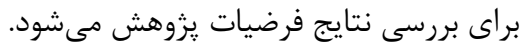

لازم به ذكر است كه براى تحليل آمارى نيز از نرم افزار

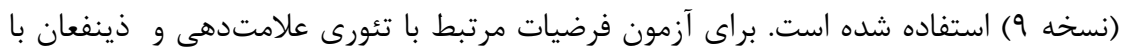

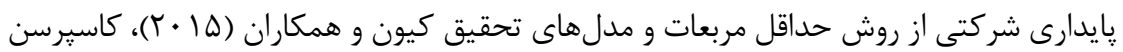

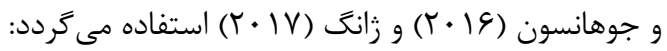
مدل آزمون فرضيه اصلى دوم: (كاسبرسن و و جوهانس (Y) $C S D_{i t}=\beta_{0}+\beta_{1} R O A_{i t}+\beta_{2} C S E_{i t}+\beta_{3} \operatorname{SIZE}_{i t}+\beta_{4} L E V_{i t}+\beta_{5} L I Q_{i t}+\beta_{6}$ Profit ${ }_{\text {it }}+$ eit

مدلهاى فرضيات فرعى مرتبط با فرضيه اصلى دوم: $C G c o$ it $=\beta_{0}+\beta_{1} R O A_{i t}+\beta_{2} C S E_{i t}+\beta_{3} F O W N_{i t}+\beta_{4} S I Z E_{i t}+\beta_{5} L E V_{i t}+$ eit

$C E c o_{i t}=\beta_{0}+\beta_{1} R O A_{i t}+\beta_{2} C S E_{i t}+\beta_{3} \operatorname{SIZE}_{i t}+\beta_{4} L E V_{i t}+\beta_{5} L I Q_{i t}+\beta_{6}$ Profit $_{\text {it }}+$ eit

$C E n v_{i t}=\beta_{0}+\beta_{1} R O A_{i t}+\beta_{2} C S E_{i t}+\beta_{3} S I Z E_{i t}+\beta_{4} L E V_{i t}+$ eit

$C S O c_{i t}=\beta_{0}+\beta_{1} R O A{ }_{i t}+\beta_{2} C S E_{i t}+\beta_{3} S I Z E_{i t}+\beta_{4} L E V_{i t}+\beta_{5}$ Profit $_{i t}+$ eit مدل آزمون فرضيه اصلى سوم: (زانگ، $C S D_{i t}=\beta_{0}+\beta_{1} G O W N_{i t}+\beta_{2} L O W N_{i t}+\beta_{3} S_{Z I Z E_{i t}}+\beta_{4} L E V_{i t}+\beta_{5} L I Q_{i t}+$ $\beta_{6}$ Profit $_{\text {it }}+$ eit

مدلهاى فرضيات فرعى مرتبط با فرضيه اصلى سوم: $C G c o$ it $=\beta_{0}+\beta_{1} G O W N_{i t}+\beta_{2} L O W N_{i t}+\beta_{3} S I Z E_{i t}+\beta_{4} L E V_{i t}+$ eit 
$C E c o_{i t}=\beta_{0}+\beta_{1} G_{O W N}+\beta_{2} L O W N_{i t}+\beta_{3} S_{Z I Z}{ }_{i t}+\beta_{4} L E V_{i t}+\beta_{5} L I Q_{i t}+$ $\beta_{6}$ Profit it + eit

$C E n v_{i t}=\beta_{0}+\beta_{1} G O W N_{i t}+\beta_{2} L O W N_{i t}+\beta_{3} S_{Z I Z E_{i t}}+\beta_{4} L E V_{i t}+$ eit

CSOc $_{i t}=\beta_{0}+\beta_{1}$ GOWN $_{i t}+\beta_{2} L O W N_{i t}+\beta_{3}$ SIZE $_{i t}+\beta_{4} L E V_{i t}+\beta_{5}$ Profit $_{i t}$ + eit

در اين مدلها متغيرهاى CSD CSCoc , CEnv،CEco CCGco به ترتيب شاخص كل

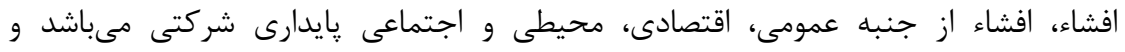

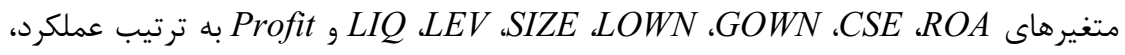

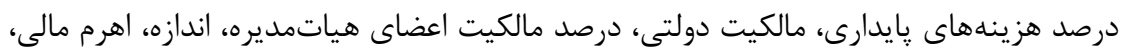

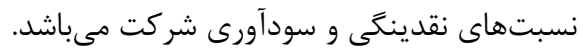

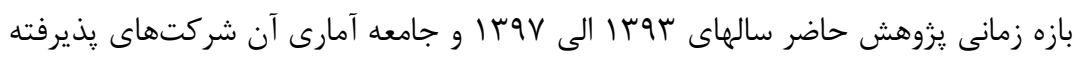

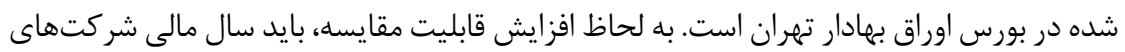

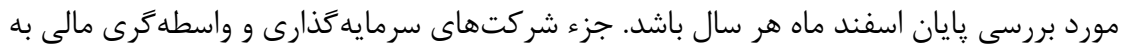

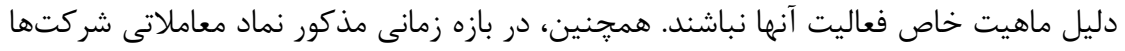

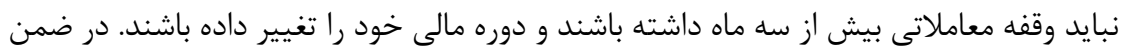

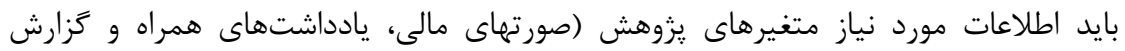

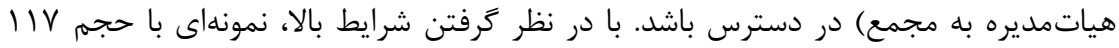

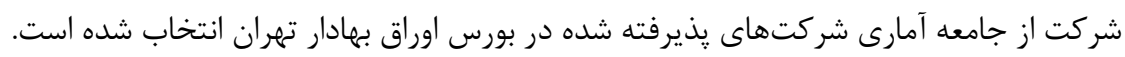

\section{• نحوه اندازهيرى و تعريف متغيرهاى :ثزوهش}

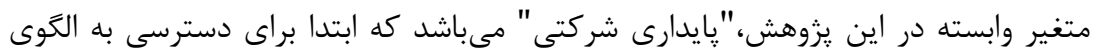

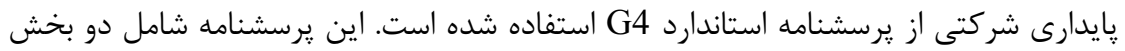

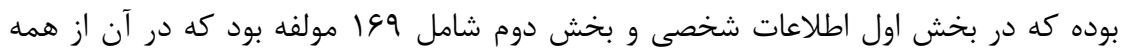

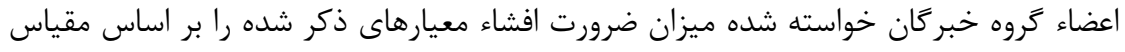

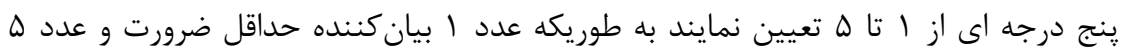

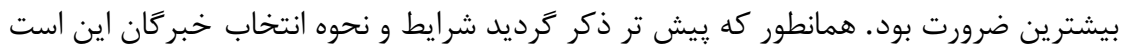

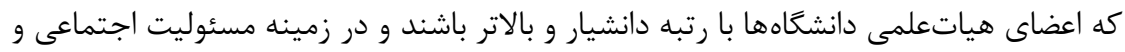

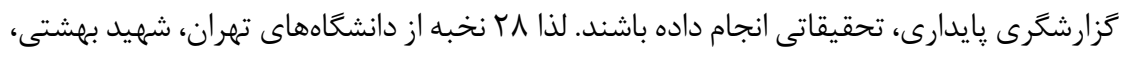

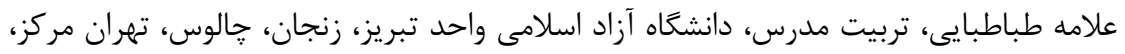

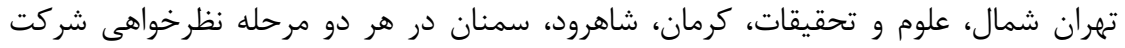

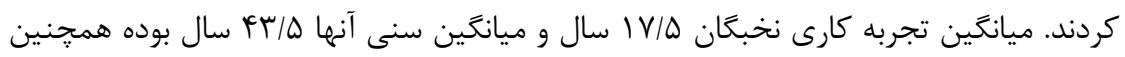

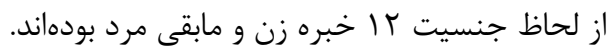


يس إز اينكه يرسشنامه به خبركان توزيع كرديد اقدام به بررسى اجماع نظر خبركان شد در

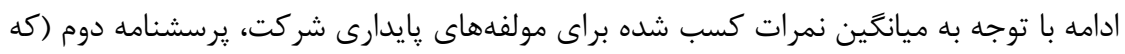

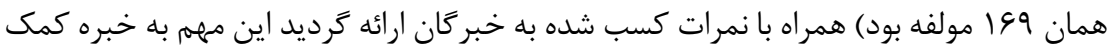
كرد تا تفاوت نظرات خودش را با جمع متوجه شود و در صورت نياز نظر خود را تعديل نمايد.

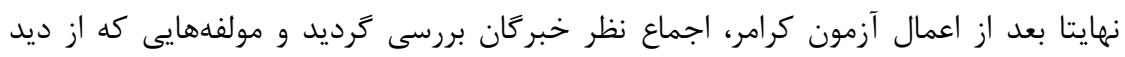

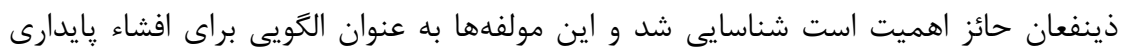

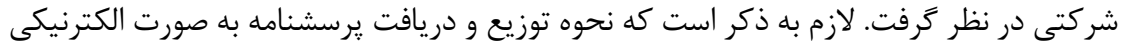

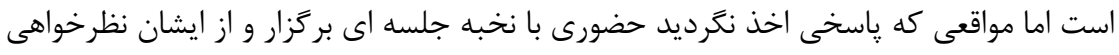

در ادامه مولفههاى مربوط به بخشهاى بايدارى شركتى در قسمت يافتههاى فرضيه اول ارائه

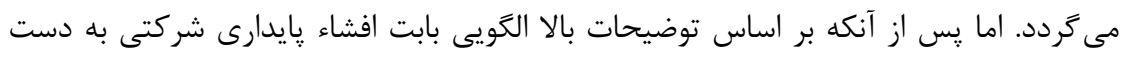

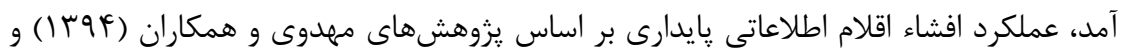

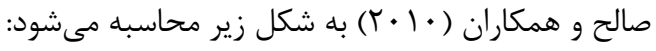
Docs $=\sum_{j=1}^{n} \frac{D j}{n}$

Dacs

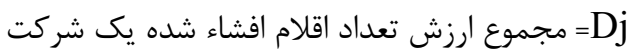
n حداكثر امتيازى كه يك شركت مى توانست كسب كند ( • م مولفه طبق نتايج آزمون فرضيه

براى محاسبه مجموع ارزش تعداد اقلام افشاء شده شركتهاى منتخب، از الكوى •N مولفه

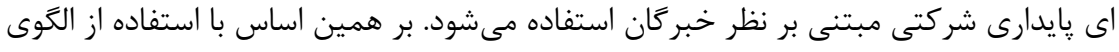

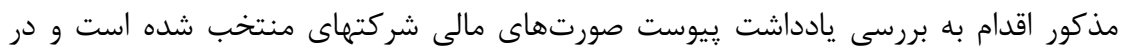

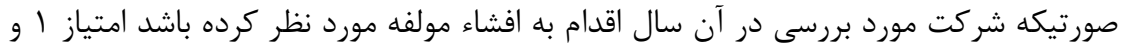

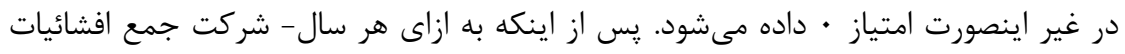

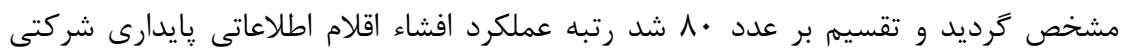
مشخص مىشود. متغير مستقل در اين بروهش عوامل مرتبط با تئورى علامتدهى و ذينفعان مىباشد كه به شرح

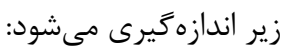


عملكرد شركت: براى اندازهخيرى اين متغير از نسبت بازده دارايى استفاده مىشود به به طورى كه

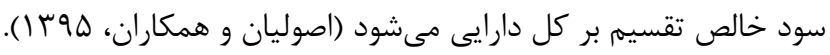

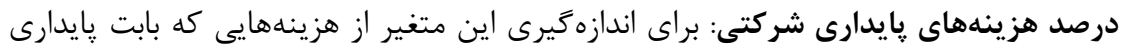

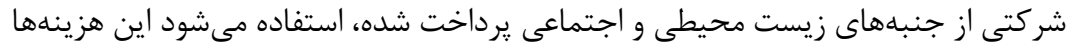

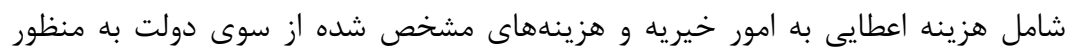

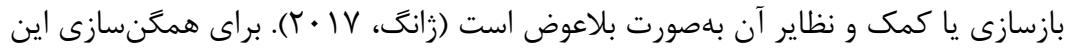

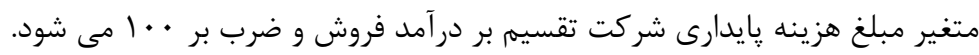

\section{• عوامل مرتبط با تئورى ذينفعان:}

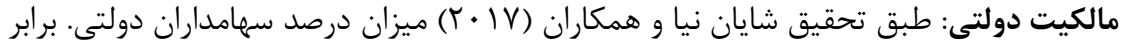

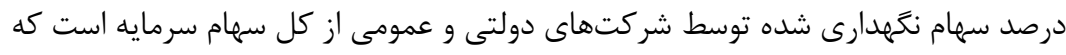

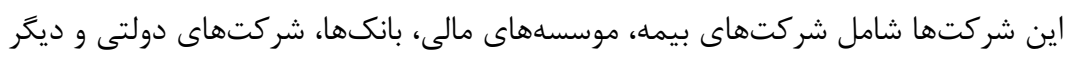

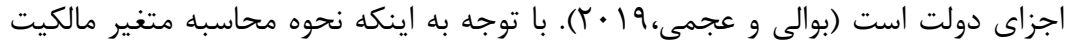

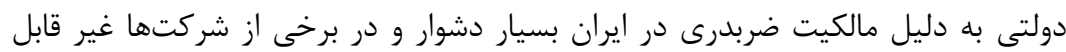

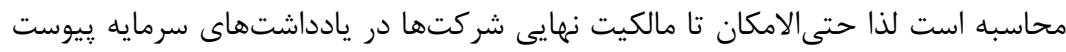

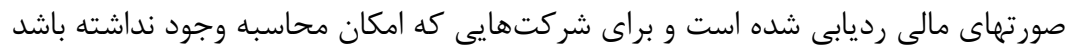
از نمونه تحقيق حذف كرديده است. درصد مالكيت اعضاى هياتمديره: ميزان درصد سهامداران اعضاى هياتمديره، برابر با دردان درصد سهام نكهيدارى شده توسط اعضاى هياتمديره از كل سهام سرمايه است (بوالى و داني

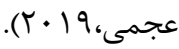

در ادامه متغيرهاى كنترلى مرتبط با پايدارى شركتى از جنبه عمومى، اقتصادى، زيست محيطى

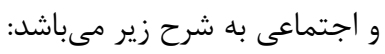

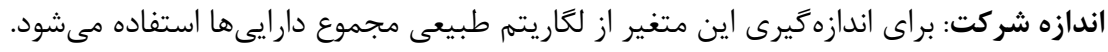

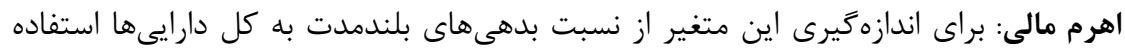

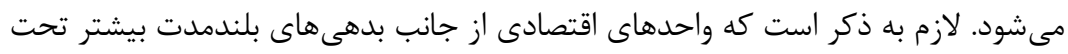

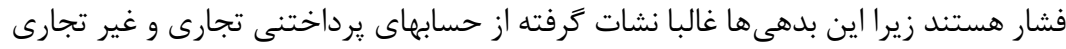

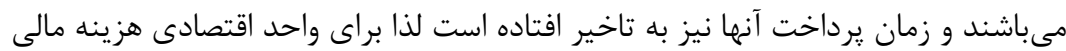

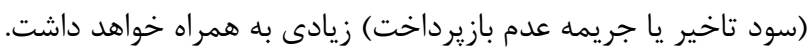




$$
\text { نسبت نقدينكى: جمع دار ايىهاى نقد و شبه نقد/ جمع دار ايىها }
$$

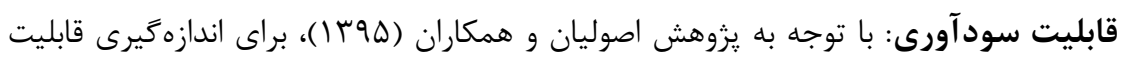
سودآورى از نسبت تغييرات سود خالص نسبت به سال قبل استفاده مىشود.

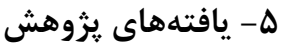

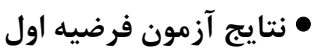

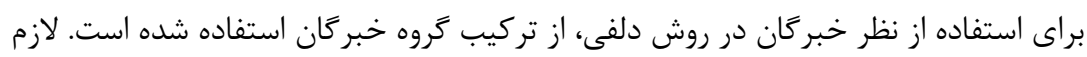

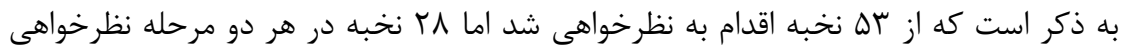

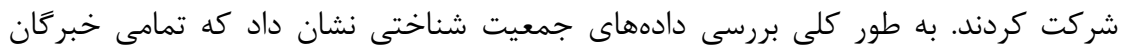

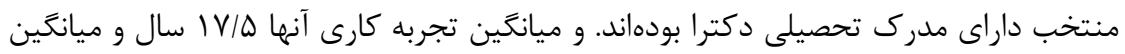

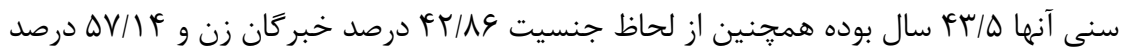

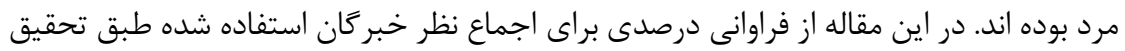

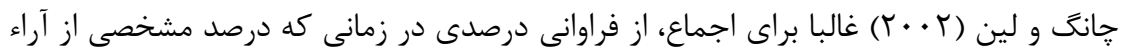

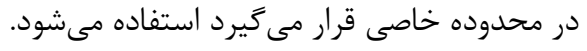

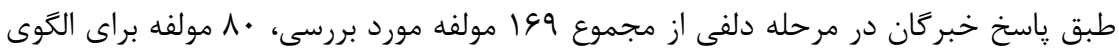

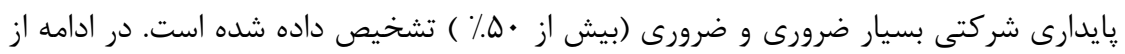
ضريب كندال براى تعيين ميزان اجماع نظر ميان اعضاى پاسخ دهندكان استفادهاد كرديده كه

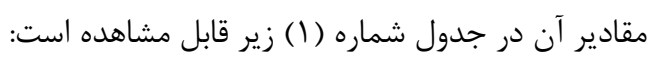

\begin{tabular}{|c|c|c|}
\hline (مرحله دوم) & (مر حله اول) & تعداد خبركان ( Y^ نفر) \\
\hline$\cdot \mid \mathrm{A} \cdot r$ & $\cdot / 1 \Delta \Lambda$ & كندال ضريب \\
\hline TVVG/FAT & $|r / \Delta V|$ & دو خى ضريب \\
\hline 191 & 191 & آزادى درجه \\
\hline $.1 \%$ & $.1 \cdot 09$ & اطمينان بازه \\
\hline
\end{tabular}

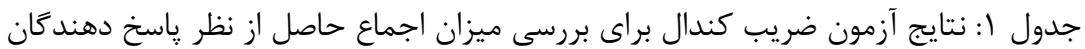

از آنجايى كه مرحله دلفى براى دو بار تكرار شد در دور دوم توافق بين خبركان حاصل شد الدا

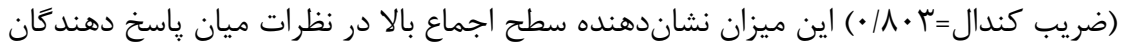

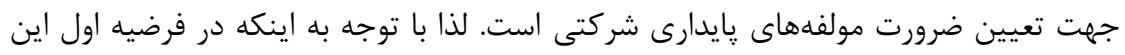

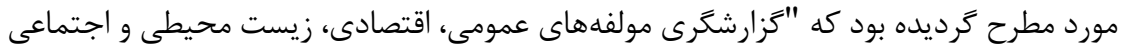

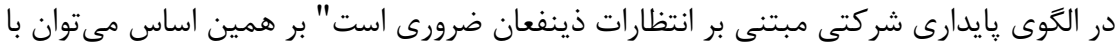


$\varepsilon+r$ دكتر جهانشاد و همكاران، ارائه الكَيى براى افشاء اطلاعات پِايدارى شركتى و ارزيابى اثرعوامل ...

استفاده از آزمون صورت كرفته در جدول (1) و مولفههاى نهايى پايدارى شركتى، نتيجه اين

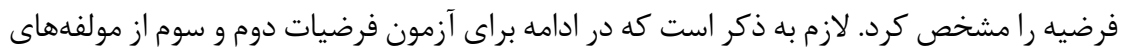
مورد توافق در الكَى يايدارى شركتى به عنوان جُى ليست افشاء پِايدارى شركتى استفاده

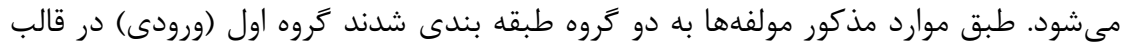

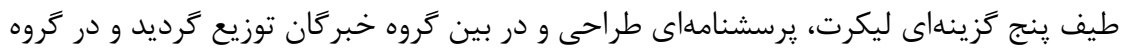

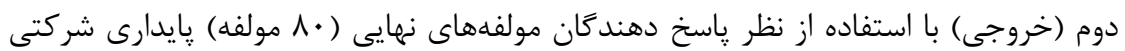
مشخص كرديد كه نتايج آن به شرح جدول شماره (r) است. جدول r: نتايج مربوط به فراوانى پاسخ دهندكان به مولفه هاى بايدارى شركتى (در آخرين

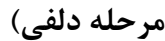

\begin{tabular}{|c|c|c|c|c|c|c|}
\hline $\begin{array}{l}\overline{3} \\
\hat{\lambda} \\
0 \\
2 \\
\hat{2} \\
0 \\
\frac{3}{5} \\
5\end{array}$ & 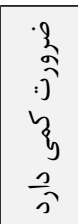 & $\begin{array}{l}3 \\
3 \\
3 \\
2 \\
\frac{3}{9} \\
\frac{3}{3} \\
3\end{array}$ & \begin{tabular}{c}
2 \\
5 \\
$y$ \\
$\bar{y}$ \\
\hdashline 3
\end{tabular} & $\begin{array}{c}3 \\
3: \\
2 \\
2 \\
2 \\
\bar{y} \\
\overline{3} \\
: 3\end{array}$ & مولفه هاى حسابدارى محيط زيست & رديف \\
\hline \multicolumn{7}{|c|}{ افشاء بخشها و مولفههاى پايدارى شركتى از جنبههاى عمومى: } \\
\hline \multicolumn{7}{|c|}{ افشاء مولفههاى مرتبط با نمايه سازمان } \\
\hline- & - & - & $\% \notin \varepsilon / 4$ & $\% / \Delta / 9$ & |نام سازمان & 1 \\
\hline- & $\% / / 1$ & $\%$ \%N/9 & $\%$ & $\% / r \Delta / \cdot$ & |فعاليتها، برندها، محصولات و خدمات & r \\
\hline- & $\% / 4$ & $\% r \Delta / \cdot$ & $\% \sim r \Delta / \mathrm{v}$ & $\% / r \Delta / v$ & |موقعيت جغرافيايى مركز اصلى سازمان & r \\
\hline- & $\% 1 \% / \mu$ & $\% 1 \mathrm{~V} / 9$ & $\%$ \%৭/५ & $\%$ /rN/9 & |موقعيت جغرافيايى محل عمليات & F \\
\hline- & $\% 1 \cdot / \mathrm{V}$ & $\% 1 \mathrm{~V} / 9$ & $\%$ \% $/ 1$ & $\% / r q / r$ & | مالكيت و ساختار قانونى & $\Delta$ \\
\hline- & $\% / / 1$ & $\% 1 \cdot / \mathrm{V}$ & $\% .0 \cdot 1 \cdot$ & $\%$ /TT/1 & |بازارهاى ارائه محصول و خدمات & 9 \\
\hline- & - & $\% / \% / 4$ & $\% / \% 9 / \Gamma$ & $\% / . \mathrm{V} / \mathrm{I}$ & | اندازه سازمان & v \\
\hline- & - & $\% 1 \cdot / \mathrm{V}$ & $\% T r / 1$ & $\% / . \Delta \mathrm{V} / \mathrm{I}$ & |مشخصات مربوط به كارمندان و ساير كاركران & $\wedge$ \\
\hline- & $\% / \%$ & $\% 1 \% / T$ & $1.94 / T$ & $\% 1 \mathrm{~V} / 9$ & |زنجيره تامين & 9 \\
\hline- & - & $\% / \% / 4$ & $\% \sim \Delta / \mathrm{V}$ & $\% .9 \cdot / \mathrm{V}$ & |تغييرات قابل توجه در سازمان و زنجيره تامين & 1. \\
\hline$\% / T \wedge / 9$ & - & $\% \mathrm{~V} / \mathrm{I}$ & $\% \pi r / 1$ & $\% / r T / 1$ & |عضويت در انجمنها & 11 \\
\hline \multicolumn{7}{|c|}{ افشاء مولفههاى مرتبط با استراتزى سازمان } \\
\hline- & - & $\%$ \%N/9 & $\%$ FT/9 & $\%$ / $\wedge / 9$ & |بيانيه تصميم كَيرنده ارشد سازمان & ir \\
\hline- & - & $\% / \%$ & $\% / T \wedge / 9$ & $1.9 \mathrm{~V} / 9$ & |تاثيرات اصلى، تهديدها و فرصتها & 14 \\
\hline- & - & $\% 1 \mathrm{~V} / 9$ & . & $\% / \Delta \cdot 1 \cdot$ & |رزشها ، اصول ، معيارها و هنجارهاى رفتارى & 14 \\
\hline
\end{tabular}


دو فصلنامه حسابدارى ارزشى و رفتارى، سال ينجم، شماره دهم، پإييز و زمستان وجسا

\begin{tabular}{|c|c|c|c|c|c|c|}
\hline \multicolumn{7}{|c|}{ افشاء مولفههاى مرتبط با حاكميت شركتى } \\
\hline- & $\% \vee / 1$ & $\% / r y / r$ & $\% / \% 9 / \%$ & $\% \pi / 1$ & ساختار حاكميت شركتى & 10 \\
\hline- & $\% / \mathrm{r} / \mathrm{G}$ & $\% \mathrm{~V} / \mathrm{I}$ & $\% / \% q / \mu$ & $\% . \Delta \cdot 1 \cdot$ & |مراجع اختيارات در مباحث اقتصادى، زيست محيطى و & 19 \\
\hline- & $\% / \mathrm{r} / 9$ & $\% 1 \cdot / \mathrm{V}$ & $\% . \omega \cdot / \cdot$ & $\% \sim / \mathrm{r} / \mathrm{V}$ & محيط زيستوليت در سطح اجرايى براى موضوعات اقتصادى، & iv \\
\hline$\% 1 V / 9$ & $\% \mathrm{~V} / \mathrm{I}$ & $\% / r \Delta / \cdot$ & $\% / \mathrm{r} / \mathrm{V}$ & $\% \mid r / T$ & |تضاد منافع & 11 \\
\hline- & - & $\% . \Delta T / 9$ & $\% \mathrm{~V} / \mathrm{I}$ & $\% / \%$ / & |ستش بالاترين نهاد حاكميتى در تعيين هدف، ارزشها و & 19 \\
\hline$\% / 1$ & $\% / \mathrm{V} / \mathrm{I}$ & $\% / \mathrm{T} / \cdot$ & $\% / r / / 4$ & $\% / \% q / \mu$ & سياستهاى پاداش & $r \cdot$ \\
\hline \multicolumn{7}{|c|}{ افشاء مولفههاى مرتبط با مشاركت ذينفعان سازمان } \\
\hline- & $\% 1 \mathrm{~V} / \mathrm{q}$ & $\%$ & $\% / \mathrm{rQ} / \cdot$ & $\% 4 / 1$ & ليست گروههاى ذينفع & 41 \\
\hline- & $\% / \mathrm{r} / \mathrm{s}$ & $\% 1 \mathrm{~V} / 9$ & $\% .9 \cdot / \mathrm{V}$ & $\% 1 \mathrm{~V} / 9$ & شناسايى و انتخاب ذينفعان & tr \\
\hline- & $\% \mathrm{~V} / \mathrm{I}$ & $\% / \mathrm{TN} / 9$ & $\%$ /rt/ & $\% T / 1$ & | رويكرد مشاركت با ذينفعان & r \\
\hline- & $\% \cdot 1 \mathrm{~V}$ & $\%$.TN/9 & $\% \notin T / Q$ & $\% 1 \mathrm{~V} / 9$ & موضوعات كليدى و نكرانىهاى مطرح شده & tr \\
\hline \multicolumn{7}{|c|}{ افشاء مولفههاى مرتبط با محتواى كزارش پايدارى سازمان } \\
\hline- & $\% / \mathrm{H} / \mathrm{s}$ & $\%$ & $\% F r / 9$ & $\% \mathrm{l} / \mathrm{T}$ & تعيين محتواى افشاء و تفكيك موضوعات & ra \\
\hline- & $\% / / 1$ & $\% \mathrm{~V} / \mathrm{I}$ & $\% / \% q / \Gamma$ & $\% \uparrow \varepsilon / 4$ & ليست موضوعات مادى & rq \\
\hline- & - & $\% / \mathrm{V} / \mathrm{I}$ & $\% . \Delta \mathrm{V} / \mathrm{I}$ & $\% \mathrm{r \Delta} / \mathrm{V}$ & | (دوره گزارش & tr \\
\hline- & - & $\% / \mathrm{V} / \mathrm{I}$ & $\% \cdot \omega \cdot 1 \cdot$ & $\%$ \& $/ 9$ & تاريخ آخرين گزارش & $r \Lambda$ \\
\hline- & - & $\% / \mathrm{V} / 1$ & $\% / \mathrm{r \Delta} / \cdot$ & $\% .9 \mathrm{~V} / 9$ & جرخه كزارش & $4 q$ \\
\hline- & $\% \mathrm{~V} / \mathrm{I}$ & $\% / \mathrm{TQ} / \cdot$ & $\% / T / / 4$ & $\% \varphi q / 4$ & مرجع ياسخكَيى در خصوص سوالات عطف به كَزارش & $r \cdot$ \\
\hline \multicolumn{7}{|c|}{ افشاء مولفههاى مرتبط با هيات مديره سازمان } \\
\hline- & - & $\% / \mathrm{TN} / 9$ & $\% F r / q$ & $\% / r \wedge / 9$ & |قدام هيات مديره در خصوص مستند سازى و استقرار ساز & r \\
\hline- & - & - & $\% 1 \mathrm{~V} / 9$ & $\%$. $.1 T / 1$ & مشخصات اعضاى هيات مديره & rt \\
\hline- & $\% / \mathrm{r} / 9$ & $\% 1 \% / \pi$ & $\% 1 \mathrm{~V} / 9$ & $\% .94 / \mathrm{K}$ & تعداد اعضاء هيات مديره & r \\
\hline- & & & $\% \mathrm{~V} / \mathrm{I}$ & $\% 9 r / 9$ & تعداد اعضاء موظف و غير موظف هيات مديره & re \\
\hline- & $\% \mathrm{~V} / \mathrm{I}$ & $\% / R T / 4$ & $\% \notin T / Q$ & $\% / \mathrm{r} / \mathrm{g}$ & تعداد اعضاء مستقل هيات مديره & ra \\
\hline- & $\% \mathrm{~V} / \mathrm{I}$ & $\% \mathrm{~V} / \mathrm{I}$ & $\% / r \wedge / 9$ & $\% \Delta V / 1$ & |مرتبط & re \\
\hline
\end{tabular}




\begin{tabular}{|c|c|c|c|c|c|c|}
\hline- & - & $\mid / T / / 4$ & $\% 4 r / 9 \%$ & $\% r \Delta / V$ & 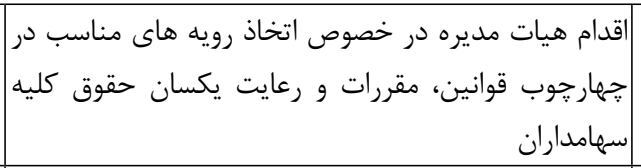 & rv \\
\hline- & $\% \mathrm{~V} / 1$ & $\% 1 \cdot / \mathrm{V}$ & $\%$ \% $/ 9 \cdot \%$ & $\% \omega r / 9$ & |قضام هيات مديره در خصوص تاييد و اجراى معاملات باس & rᄉ \\
\hline - & $\% / 4 / 9$ & $\% / \%$ & $\% / r \mid / 4$ & $\% V I / 4$ & |قنترل داخلى اثربخش مديره در خصوص استقرار ساز و كارهاى| & rq \\
\hline- & - & $\% / \%$ & $\%$ & $\% \mathrm{VI} / \mathrm{F}$ & |قدام هيات مديره در خصوص بررسى حداقل سالانه & r. \\
\hline$\% / \% / 9$ & $|\% \cdot / v|$ & $\% 1 \cdot / \mathrm{V}$ & $\% \leftarrow r / 9 \%$ & $\% r / 1$ & 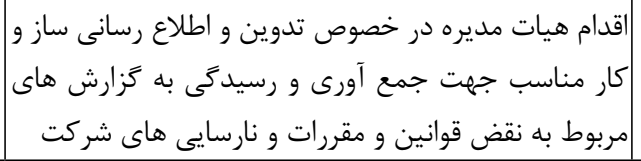 & il \\
\hline- & $\% / \%$ & $\mid / T / / 4$ & $\%$ \% $/ \cdot \cdot \%$ & $\% \cdot \Delta \cdot / \cdot$ & |قميته حسام هيات مديره در خصوص انتصابات تحت نظكيل و نظارت بر عملكرد & et \\
\hline- & $\% \mathrm{~V} / 1$ & $\mid / 14 / \pi$ & $|\% \Delta / \mathrm{r}| \%$ & $\% F r / 9$ & |اثر بخام هيات مديره در خصوص استقرار فرآيند ارزيابى سالانه & qr \\
\hline- & - & - & $\%$ /. & $\% \cdot 9 \cdot / \mathrm{V}$ & |تشكيل جلسات هيات مديره & fq \\
\hline \multicolumn{7}{|c|}{ افشاء مولفههاى مرتبط با پاسخكَويى و افشاى اطلاعات } \\
\hline- & - & $\mid / T / 4$ & 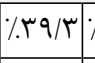 & $\%$ \% $/ / 4$ & | اطلاعات با اهميت & $i \Delta$ \\
\hline$\% / \% / 9$ & $\% \mathrm{~V} / 1$ & $\% 1 \mathrm{~V} / 9$ & $\% \notin r / 9$ & $\%$ \%N/9 & |فشاء اطلاعات لازم در زمينه مسائل مالى، اقتصادى، & is \\
\hline- & - & $\mid / T N / 9$ & $\mid \%(\pi / 1)$ & $\% / \% 9 / \%$ & | شده در رابطه ميزان تحقق برعايت اصول هاى رامميت شركتى واقدامات انجام & iv \\
\hline \multicolumn{7}{|c|}{ افشاء ساير مولفههاى مرتبط با جنبههاى عمومى } \\
\hline- & $\% \vee V / 1$ & $\% / T I / 4$ & $\%$ \% $\wedge / 9$ & $\% F r / 9$ & | موضوعات مادى & $4 \wedge$ \\
\hline- & $\% / \% / 4$ & $\% / T I / 4$ & $\% 1 \mathrm{~V} / \mathrm{q}$ & $\% \mathrm{QV} / \mathrm{I}$ & |رويكرد مديريت و مؤلفه هاى آن & $4 q$ \\
\hline$\% / \% / 9$ & $\% \vee V / 1$ & $|/ T \backslash / 4|$ & $\% / r \Delta / \cdot \cdot$ & $\% F r / 9$ & | ارزيابى رويكرد مديريت & $\Delta \cdot$ \\
\hline \multicolumn{7}{|c|}{ افشاء بخشها و مولفههاى بايدارى شركتى از جنبههاى اقتصادى: } \\
\hline- & - & - & 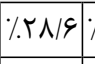 & $\% \mathrm{~V} / / \mathrm{A}$ & |رزش افزوده اقتصادى مستقيم توليدو توزيع شده & 81 \\
\hline- & $\% 1 \cdot / v$ & $\mid / T / / 4$ & 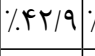 & $\% \mathrm{LQ} / \cdot$ & سرمايه كذارى هاى زير بنايى و خدمات پشتيبانى & $\Delta T$ \\
\hline- & - & $\mid / r T / 1$ & $\mid .94 / \mathrm{s}$ & $\% / \%$ & |تأثيرات اقتصادى غيرمستقيم قابل توجه & $\Delta T$ \\
\hline
\end{tabular}


دو فصلنامه حسابدارى ارزشى و رفتارى، سال ينجم، شماره دهم، پإييز و زمستان وجسا

\begin{tabular}{|c|c|c|c|c|c|c|}
\hline- & $\% \mathrm{~V} / 1$ & $\% T I / 4$ & $\% / \% 9 / \%$ & $\% / \mathrm{T} / \mathrm{T}$ & |نسبت هزينه هاى تامين كنندكان محلى & $\Delta f$ \\
\hline- & $\%$ & $\%$ \%N/9 & $\% \cdot \omega \cdot 1 \cdot$ & $\% 1 \mathrm{~V} / 9$ & |رزيابى عمليات مرتبط با خطر فساد & $\Delta \Delta$ \\
\hline \multicolumn{7}{|c|}{ افشاء بخشها و مولفههاى پايدارى شركتى از جنبههاى زيست محيطى: } \\
\hline- & - & - & $\% \varphi \varepsilon / 4$ & $\% \Delta / \varphi$ & |ميزان مواد مورد نياز بر اساس وزن و حجم & $\Delta \varphi$ \\
\hline- & $\% / \mathrm{T} / 9$ & $\% 1 \cdot / \mathrm{V}$ & $\% \vee \vee \Delta / \cdot$ & $\% 1 \cdot / V$ & |استفاده از مواد بازيافتى بعنوان مواد وارده به جرخه توليد & $\Delta V$ \\
\hline - & - & $\% / \mathrm{r} / \mathrm{s}$ & $\% F r / q$ & $\% \Delta r / 9$ & |كل مصرف سوخت سازمان از منابع تجديد يذير و غير & $\Delta \Lambda$ \\
\hline- & - & $\% \mathrm{~V} / \mathrm{I}$ & $\% \omega \Delta / \mathrm{r}$ & $\% \Delta \mathrm{V} / \mathrm{T}$ & |ميزان مصرف انرزى & $\Delta 9$ \\
\hline- & $\% 1 \cdot / \mathrm{V}$ & $\% / T I / 4$ & $\% \pi / 1$ & $\% \omega \Delta / V$ & 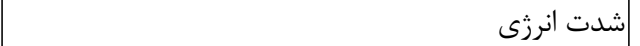 & q. \\
\hline- & $\% 1 \cdot / \mathrm{V}$ & $\% 1 \cdot / \mathrm{V}$ & $\% \varphi q / 4$ & $\% t / 1$ & |ميزان كاهش در مصرف انرزى & 9) \\
\hline- & $\% \mathrm{~V} / \mathrm{I}$ & $\%$ & $\% / \mathrm{r} \wedge / \varphi$ & $\% / r \Delta / \cdot$ & |ميزان كاهش در انواع انرزى & gr \\
\hline- & $\% / \mathrm{r} / 9$ & $\% \mathrm{r \Delta} / \cdot$ & $\% F r / q$ & $\% / r \wedge / 9$ & برداشت آب از منابع & M \\
\hline- & $\% \mathrm{~V} / \mathrm{I}$ & $\% 1 \cdot / \mathrm{V}$ & $\% / r \Delta / \cdot$ & $\% . \Delta \mathrm{V} / \mathrm{I}$ & تاثير پذيرى منابع آب از برداشت آب & gr \\
\hline$\%$ \%/9 & - & $\%$ / $/ \mathrm{L} / \cdot$ & $\% .9 \cdot / V$ & $\% / 1 \cdot / \mathrm{V}$ & |بازيافت آب و استفاده مجدد & 90 \\
\hline- & $\% \mathrm{~V} / \mathrm{I}$ & $\% \mathrm{~V} / \mathrm{I}$ & $\% / \Delta r / \varphi$ & $\% / r / 1$ & |توليد گازهاى گلخانه اى مستقيم & 49 \\
\hline- & $\% / \mathrm{r} / 9$ & $\% \mathrm{~V} / \mathrm{I}$ & $\% .94 / \pi$ & $\% / r \Delta / \cdot$ & |ضايعات بر اساس نوع و روش دفع & $9 V$ \\
\hline- & $\% 1 \cdot / \mathrm{V}$ & $\% \mathrm{~V} / \mathrm{I}$ & $\% . \Delta \mathrm{V} / \mathrm{I}$ & $\% / r \Delta / \cdot$ & |عدم انطباق با قوانين و مقررات زيست محيطى & $9 \wedge$ \\
\hline- & $\% / \mathrm{r} / 9$ & $\% \mathrm{~V} / \mathrm{I}$ & $\% .9 \cdot / V$ & $\% / r \wedge / 9$ & |فعاليت هاى انجام شده در خصوص ايجاد و توسعه كميته & 99 \\
\hline- & - & $\% \mathrm{~V} / \mathrm{I}$ & $\% / \mathrm{rQ} / \cdot$ & $\% .9 \mathrm{~V} / 9$ & | بياده سازى و رعايت استاندارد هاى زيست محيطى داخلى| & $V$. \\
\hline- & $\% / \mathrm{T} / \mathrm{9}$ & - & $\% \vee \wedge / 9$ & $\% 1 \mathrm{~V} / 9$ & | طمبيعى & VI \\
\hline- & - & - & $\% \varphi q / 4$ & $\% \Delta / \Delta / \varphi$ & | هر گونه عمليات مرتبط با مديريت بهينه سازى استفاده از & vr \\
\hline- & - & - & $\% 1 \mathrm{~V} / 9$ & $\% . \Lambda 4 / 1$ & |فعاليت هاى مرتبط با فرهنَ سازى و آموزش هاى لازم & vr \\
\hline- & - & $\% \mathrm{~V} / \mathrm{I}$ & $\% F r / q$ & $\% \cdot \omega \cdot / \cdot$ & | فعاليت هاى مرتبط در خصوص تحقيق و توسعه جهت & $V F$ \\
\hline- & - & $\% 1 \% / \pi$ & $\mid / Y T / 4$ & 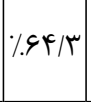 & |مرتبزان صرفه جويى و سود دهى در استفاده از منابع طبيعى| & \\
\hline
\end{tabular}




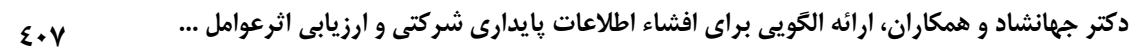

\begin{tabular}{|c|c|c|c|c|c|c|}
\hline \multicolumn{6}{|r|}{ |افشاء بخشها و مولفههاى پايدارى شركتى از جنبههاى اجتماعى: } & \multirow{2}{*}{ VQ } \\
\hline- & $\% / \%$ & $\% 1 \mathrm{~V} / 9$ & $\% \vee \vee \Delta / \cdot$ & $\% / \varphi$ & |مزاياى ارائه شده به كارمندان تمام وقت كه براى كارمندان & \\
\hline \multirow[t]{2}{*}{-} & - & $\% \mathrm{~V} / 1$ & $\%$.Ar/I & $\% 1 \cdot / \mathrm{V}$ & 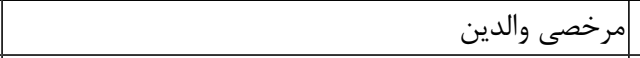 & VV \\
\hline & $\% / 4$ & $\%$ \%Q $/ \cdot$ & $\% .9 \mathrm{~V} / 9$ & $\% / \mathrm{H}$ & |كميته رسمى مشترك مديريت بهداشت و ايمنى كارگران & $\vee \wedge$ \\
\hline$\% 1 \cdot / \mathrm{V}$ & $\% \mathrm{~V} / \mathrm{I}$ & $\%$ \%N/9 & $\%$ \& $/ 9$ & $\% 1 \cdot / \mathrm{V}$ & |ميانگَين ساعت آموزش در سال به ازاى هر كارمند & Vq \\
\hline- & - & $\% F T / Q$ & $\% \sim \Delta / V$ & $|/ r| / F$ & |حوادث عدم رعايت بهداشت و تأثيرات ايمنى محصولات و & $\Lambda$. \\
\hline
\end{tabular}

تانتايج آمار توصيفى و نرماليته فرضيه دوم و سوم

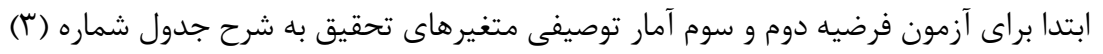

ارائه مى

جدول r: آمار توصيفى متغيرهاى تحقيق

\begin{tabular}{|c|c|c|c|c|c|c|c|}
\hline كشيدكى & |جولكى | & انحراف & كمينه & بيشينه & ميانه & ميانغين & متغير \\
\hline T/VAT & $\cdot / F Y$ & $\cdot|\cdot \Delta|$ & $.1 .9 T$ & $\cdot \mid \Delta \wedge \mathrm{V}$ & . IST & .1190 & بايدارى شركتى (CSD) شاخص كل \\
\hline$r / T \Delta \varphi$ & $\cdot / T \Delta \Lambda$ & $\cdot / \cdot \Delta \Delta$ & $\cdot / \cdot \Lambda \cdot$ & $\cdot 109$ & $\cdot \pi \cdot$ & $\cdot K \cdot r$ & 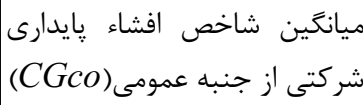 \\
\hline$r /|9|$ & $\cdot / \Delta V T$ & $\cdot / \cdot \Delta \Delta$ &.$/ \cdots$ & $.19 .$. & $\cdot \pi \cdot \cdot$ & $\cdot / T \cdot V$ & 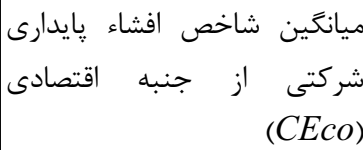 \\
\hline$r / 9 \Delta r$ & $\cdot / \mu \psi$. & $\cdot / \cdot \wedge \Delta$ & $\cdot 1 \cdots$ & $\cdot / \Delta \Delta \cdot$ & $\cdot / \cdot \Delta \cdot$ & $.1 . \wedge \mathrm{F}$ & شيانگين شاخص افشاء رِايدارى \\
\hline$F / .4 q$ & $\cdot \pi \cdots$ & $\cdot / 1 \Delta \Delta$ & $\cdot 1 \cdots$ & $1 / \cdots$ & $\cdot / \ldots$ & $\cdot / \cdot \Delta \Delta$ & شيانگين شاخص افشاء يايدارى \\
\hline $4 / .19$ &.$/ 491$ &.$/ 149$ & $-0 / \pi \xi 4$ & .1941 & .1111 &.$/ 1 \% 1$ & عملكرد شركت (ROA) \\
\hline rN/ITr & $F / . \Delta q$ & $\cdot / \cdot \Delta T$ & $\cdot \cdots$ & $.19 \mathrm{VI}$ & $\cdot / \cdot \Delta \Lambda$ & .1 .91 & 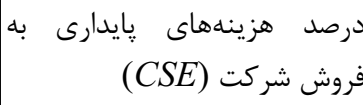 \\
\hline $1 / \Delta \Delta \Delta$ &.$- / \cdot \Delta T$ & א זr/ן &.$/ \cdots$ & .1994 &.$/ 4 \& 4$ & . /4rq & مالكيت دولتى (GOWN) \\
\hline
\end{tabular}


دو فصلنامه حسابدارى ارزشى و رفتارى، سال ينجم، شماره دهم، پإييز و زمستان و9"1

\begin{tabular}{|c|c|c|c|c|c|c|c|}
\hline$r / \cdot 11$ & $-\cdot \cdot 9 \cdot 9$ & D & $\cdot 1 \cdot r \cdot$ &.$/ 994$ & $\cdot / V \cdot \Delta$ & $\cdot \mid \varepsilon \Delta \Lambda$ & $\begin{array}{c}\text { مالكيت اعضاى هياتمديره } \\
\text { (LOWN) }\end{array}$ \\
\hline T/ATH & $\cdot|\& \Delta|$ & I/VVG & 1.1199 & 19/VVT & $\mid F / \mu f$. & $\mid f / 994$ & اندازه شركت (SIZE) \\
\hline$|\varepsilon / \Gamma| 1$ & $r / \cdot \Delta l$ & $.1 \cdot 90$ & $\cdot 1 \cdots$ & •/ATV & $\cdot|\cdot|+\mid$ & $\cdot 1 \cdot V F$ & اهرم مالى (LEV) \\
\hline $1 \cdot / r \mid \pi$ & $r / 019$ & $\cdot / \cdot \wedge \Delta$ & $\cdot 1 \cdots$ & $\cdot \mid D F F$ & $\cdot 1 \cdot r q$ & $\cdot / \cdot V \cdot$ & نقدينكى (LIQ) \\
\hline$r / 419$ & $-\cdot \cdot \cdot r \mid$ & $1 / \pi \ldots$ & $-r / 919$ & T/GYA & $\cdot 11 \cdot 9$ & . & سودآورى (Profit) \\
\hline
\end{tabular}

تحليل توصيفى متغيرهاى كمى در جداول بالا ارائه كرديده برخى از متغيرها از جمله مالكيت

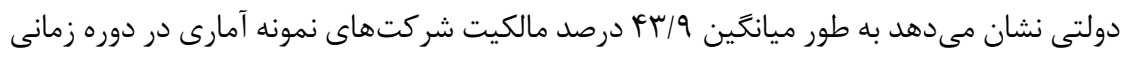
تحقيق از جانب دولت مىباشد همجنين متغير عملكرد شركت نشان مىدهد كه به طور متوسط

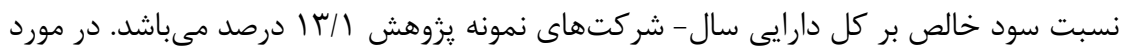
ضريب جولتى منفى برخى از متغيرها نيز ميتوان كفت كه اين موضوع حاكى از وجود جوله به به به

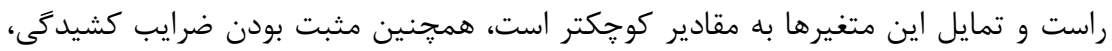

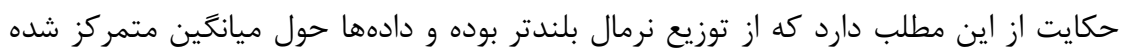
است. در ادامه يكى از مهممترين فرضيههاى رگرسيونى، نرمال بودن توزيع متغيرهاى وابسته مىباشد

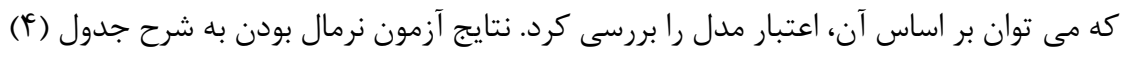
مىباشد.

جدول fا: نتايج بررسى نرمال بودن توزيع متغيرهاى وابسته

\begin{tabular}{|c|c|c|}
\hline سعنادارى سطح & آماره JB & متغيرهاى وابسته تحقيق \\
\hline.$/ 1 T \Delta$ & $V / \cdot \Delta \cdot$ & ميانگين شاخص كل افشاء پايدارى شركتى (CSD) \\
\hline - & $9 / 490$ & ميانكين شاخص افشاء يايدارى شركتى از جنبه عمومى (CGCO) \\
\hline$\cdot 1 \cdot 90$ & १/^ & ميانكين شاخص افشاء پايدارى شركتى از جنبه اقتصادى (CECO) \\
\hline$\cdot / 1 T \Lambda$ & $9 / 9 \Delta \wedge$ & ميانگين شاخص افشاء پايدارى شركتى از جنبه محيطى (CEnv) \\
\hline$\cdot / 1 \cdot r$ & $\Lambda / \cdot \Delta \cdot$ & ميانگين شاخص افشاء پايدارى شركتى از جنبه اجتماعى (CSOC) \\
\hline
\end{tabular}

مقادير سطح معنى دارى آزمون جاركوبرا براى متغيرهاى وابسته بالاتر از ه • • م مىباشد بنابراين

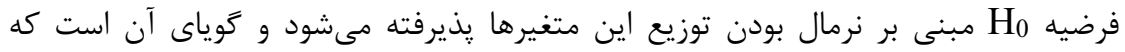
متغيرهاى وابسته تحقيق داراى توزيع نرمال مىباشد. 
$\varepsilon+q$ دكتر جهانشاد و همكاران، ارائه الكَويى براى افشاء اطلاعات يايدارى شركتى و ارزيابى اثرعوامل ...

ه نتايج آمار استنباطى و بر آورد مدلهاى فرضيه دوم و سوم

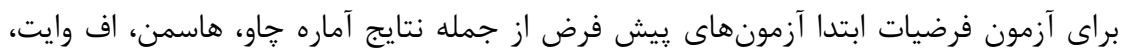

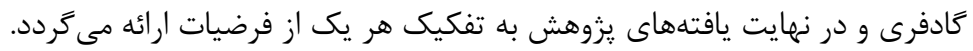

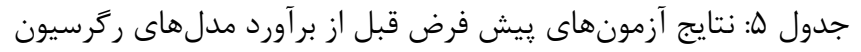

\begin{tabular}{|c|c|c|c|c|c|c|c|c|}
\hline \multicolumn{2}{|c|}{ نتايج آماره كادفرى } & \multicolumn{2}{|c|}{ نتايج آماره اف وايت } & \multicolumn{2}{|c|}{ نتايج آماره هاسمن } & \multicolumn{2}{|c|}{ نتايج آماره جاو } & \multirow[b]{2}{*}{ فرضيه تحاى } \\
\hline $\begin{array}{c}\text { سطنادارى } \\
\text { (Prob. ) }\end{array}$ & آماره & معنادارى & مقدار & معنادارى & مقدار آماره & معنادارى & مقدار & \\
\hline$\cdot / 1 \cdots$ & & $\cdot 1 \cdot \cdots$ & T/NA & $\cdot 1 \cdots$ & $\Delta N / 1 / T$ & $\cdot 1 \cdots$ & $q / 1 \cdot \Delta$ & فرضيه r \\
\hline.$/ 191$ & $r / r G \Lambda$ & $.1 \cdots$ & r/VVF & $.1 \cdots$ & $119 / 491$ & $.1 \cdots$ & N/QAT & فرضيه r-1 \\
\hline.$/ 799$ & 1/D9T & $.1 \cdot T s$ & $1 / 9 \cdot 0$ & $\cdot 1$ & $r F / r \cdot r$ & .1. & TI/ITV & فرضيه r-Y \\
\hline$\cdot / r \cdot 1$ & $T / T \Delta F$ & $.1 \cdots$ & $\Delta / F \cdot \Delta$ & $.1 \cdot .9$ & $\mid f / f \cdot V$ & $.1 \cdots$ & $T F / q \Delta G$ & فرضيه r-r \\
\hline .1 .91 & r/r.. & $\cdot 1 \cdot$ & W & $\cdot 1 \cdot \cdot 1$ & $10 / 919$ & $\cdot 1 \cdots$ & N/qFi & فرضيه r-r \\
\hline.$/ 1 \varepsilon 0$ & $r / \cdot r$. & $\cdot 1 \cdot$ & $r / 419$ & .1 & 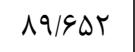 & .1 & $9 / \Gamma 4$. & فرضيه r \\
\hline$\cdot / 119$ & TRT & $\cdot 1 \cdot$ & $F / F \Delta V$ & $.1 \cdots$ & $|r V /| \cdot r$ & $\cdot 1 \cdot$ & $9 / 9 \cdot 1$ & فرضيه r-1 \\
\hline$\cdot / \pi \mid \Lambda$ & I/FTG & $\cdot / \cdots$ & r/lq. & $\cdot 1$ & $r N /|F|$ & $\cdot / \cdots$ & $r \cdot 1 \& V \Delta$ & فرضيه r-r \\
\hline$\cdot / \pi \mid \cdot$ & $r / I F \Delta$ & $\cdot 1 \cdot \cdots$ & $\Delta / r \vee q$ & .1 & TI/IAT & $.1 \ldots$ & $T Y / \cdot V T$ & فرضيه r-r \\
\hline$\cdot / \pi \cdot 0$ & Tr/T & $\cdot 1 \cdot$ & אسז/זו & $\cdot 1 \cdot$ & $r \cdot \mid \Lambda \cdot r$ & $\cdot 1 \cdot$ & $q / \cdot \Delta q$ & فرضيه r-r \\
\hline
\end{tabular}

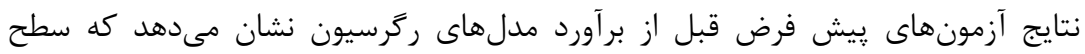

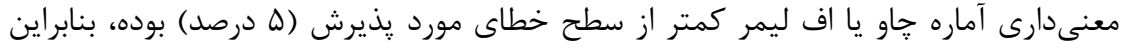

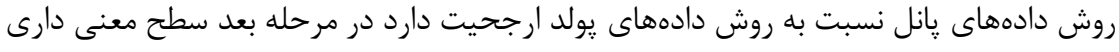

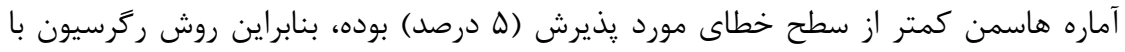

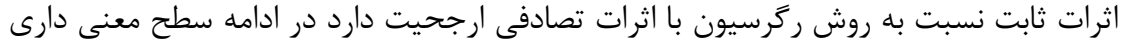

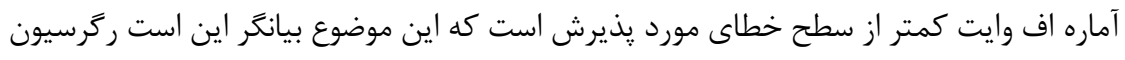

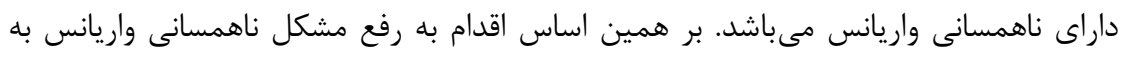

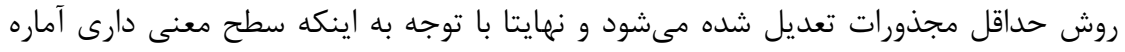

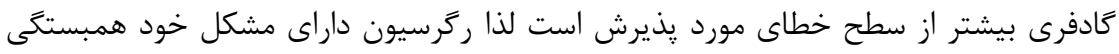
سريالى نمىباشد. 
در ادامه آزمون همخطى ميان متغيرهاى تحقيق بر اساس آماره VIF (عامل تورم واريانس)

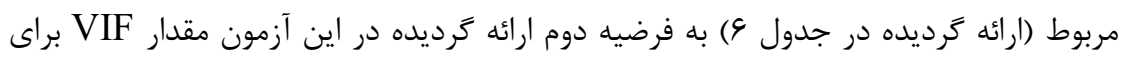

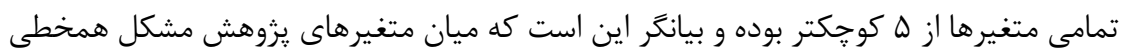
شديد وجود ندارد.

جدول 9: نتايج آماره VIF براى مدل هاى فرضيه دوم

\begin{tabular}{|c|c|c|c|c|c|}
\hline 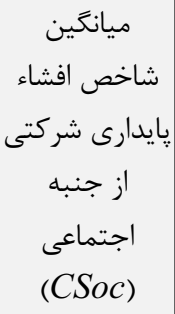 & 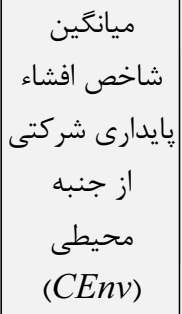 & ميانگين شاخص افشاء يايدارى & 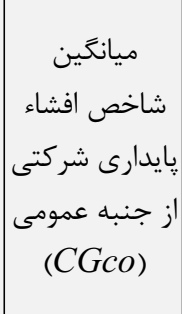 & 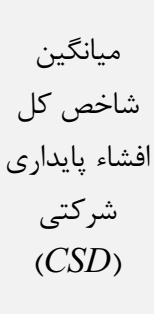 & متام و نماد \\
\hline $1 / \pi 19$ & $1 / 1 \cdot 1$ & I/DTA & $1 / 1 \cdot 1$ & l/DrA & عملكرد شركت \\
\hline $1 / \cdot r \mid$ & $1 / \cdot r$. & $1 / \cdot T r$ & $1 / \cdot T \cdot$ & $1 / . T Y$ & \begin{tabular}{|c} 
دايدارى شركت هزينهاى \\
(CSE)
\end{tabular} \\
\hline $1 / \cdot r v$ & $1 / \cdot r V$ & $1 / \cdot 4$. & $1 / \cdot r V$ & $1 / .4$. & $\begin{array}{c}\text { اندازه شركت } \\
\text { (SIZEE) }\end{array}$ \\
\hline $1 / \wedge \mathrm{V}$ & $1 / \cdot 19$ & $1 / \cdot 11$ & $1 / \cdot \wedge 9$ & $1 / \cdot \wedge \Lambda$ & $\begin{array}{l}\text { اهرم مالى } \\
\text { (LEV) }\end{array}$ \\
\hline- & - & $1 / T \cdot r$ & - & $1 / T \cdot r$ & نقدينكى (LIQ) \\
\hline $1 / \pi \cdot 9$ & - & $1 / T 11$ & - & $1 / T 11$ & $\begin{array}{l}\text { سودآورى } \\
\text { (Profit) }\end{array}$ \\
\hline
\end{tabular}

نتايج آزمون برآورد مدلهاى فرضيه دوم به شرح جدول (V) مى (V) ماشد. بر اساس نتايج جدول

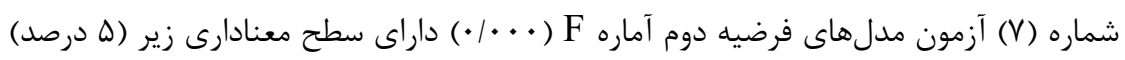

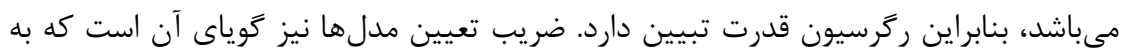

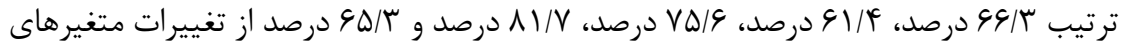

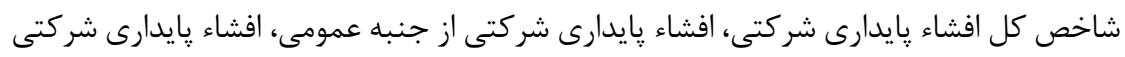

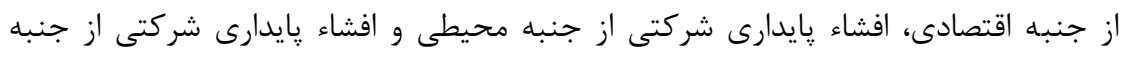

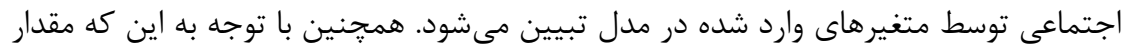

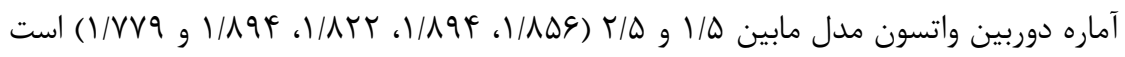


لذا مى توان كفت در مدل، مشكل خود همبستكى باقيماندها وجود ندارد. در مرحله بعد با توجه

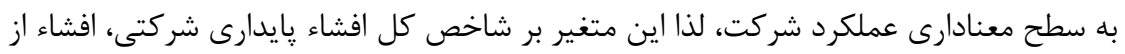
جنبه اقتصادى و محيطى تاثير مثبت معنادارى دارد.

جدول V: نتايج بر آورد مدلهاى فرضيه دوم

\begin{tabular}{|c|c|c|c|c|c|c|c|c|c|c|}
\hline \multicolumn{2}{|c|}{ 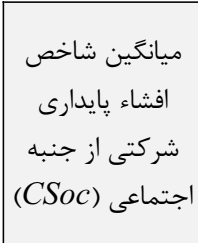 } & \multicolumn{2}{|c|}{ 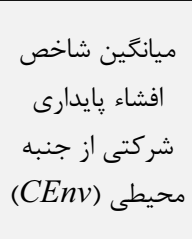 } & \multicolumn{2}{|c|}{ 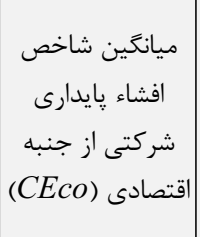 } & \multicolumn{2}{|c|}{ 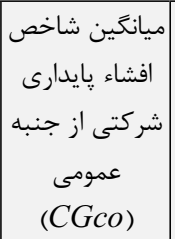 } & \multicolumn{2}{|c|}{ 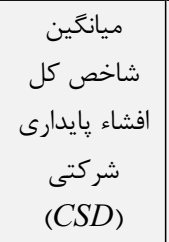 } & \multirow{2}{*}{ متنغير هاى نماد } \\
\hline $\begin{array}{l}\frac{3}{2} \\
3 \\
3 \\
\frac{2}{y}\end{array}$ & $\begin{array}{c}3 \\
3 \\
3 \\
15 \\
3 \\
3 \\
3 \\
-3\end{array}$ & $\begin{array}{l}3 \\
2 \\
3 \\
3 \\
\frac{2}{3}\end{array}$ & $\begin{array}{c}3 \\
3 \\
3 \\
12 \\
3 \\
3 \\
3 \\
3\end{array}$ & $\begin{array}{l}3 \\
2 \\
3 \\
3 \\
\frac{2}{3}\end{array}$ & $\begin{array}{c}3 \\
3 \\
3 \\
15 \\
3 \\
3 \\
3 \\
3\end{array}$ & $\begin{array}{l}3 \\
2 \\
3 \\
3 \\
\frac{2}{9}\end{array}$ & $\begin{array}{c}3 \\
3 \\
3 \\
1 \\
2 \\
3 \\
3 \\
3\end{array}$ & $\begin{array}{l}3 \\
2 \\
3 \\
3 \\
\frac{2}{9}\end{array}$ & $\begin{array}{c}3 \\
3 \\
3 \\
3 \\
3 \\
3 \\
3\end{array}$ & \\
\hline - /ArA & $.1 \% 9$ & $.1 \cdot 11$ & $\cdot / \cdot \Delta r$ &.$|\cdot r|$ & $\cdot / \cdot r f$ & $\cdot 19 \cdot 1$ & • $/ \cdot r$ &.$/ .41$ & $\cdot 1 \cdot+4$ & $\begin{array}{c}\text { عملكرد شركت } \\
(R O A)\end{array}$ \\
\hline $.1 \cdot 1 \mathrm{~V}$ & | & $.1 \cdot 10$ & $\cdot 1 \cdot v 1$ & $\cdot 1010$ & $\cdot 1 \cdot v$ & $\cdot 1 \cdot \cdot 1$ & $\cdot 1 \cdot \mathrm{V} \wedge$ & .1 .14 & .1 .94 & $\begin{array}{c}\text { دايدارى شركد هزينهاى } \\
\text { (CSE) }\end{array}$ \\
\hline$\cdot 1 \cdots$ & .1 .94 & $\cdot / \cdot r$. & $.1 \cdot .9$ & $.1 \cdot \cdot 1$ & $.1 \cdot .9$ & $\cdot 1 \cdots$ & $.1 \cdot \mathrm{Fr}$ & $\cdot 1 \cdots$ & | & $\begin{array}{c}\text { اندازه شركت } \\
\text { (SIZE })\end{array}$ \\
\hline$\cdot / \mathrm{VIN}$ & . & .1190 &.$- / \cdot Y G$ & (TrT & $.1 \cdot 99$ & $\cdot 1 \cdot 0$ & $-.1 \cdot 48$ & $. / 1<q$ &.$- / . t T$ & $\begin{array}{l}\text { اهرم مالى } \\
(L E V)\end{array}$ \\
\hline- & - & - & - & $\cdot / Q V Y$ & $-\cdot / \cdot \cdot 1$ & - & - & .1 .90 & $-.1 \cdot \mathrm{rA}$ & نقدينكى (LIQ) \\
\hline - / Frq & $-\cdot / \cdot \cdot r$ & - & - &.$/ 499$ & $\cdot / \cdots$ & - & - & $.1 \cdot 1 \cdot$ & $\cdot \cdots r$ & $\begin{array}{l}\text { سودآورى } \\
\text { (Profit) }\end{array}$ \\
\hline$\cdot \cdots$ & $-\cdot / \wedge १ ९$ &.$/ A \Lambda F$ & $-\cdot / \cdot \cdot V$ & $.1 \cdots$ & .1114 & $.1 \cdots$ & $-\cdot /$ Kr & $.1 \cdots$ & $-\cdot / K T \cdot$ & مقدار ثابت \\
\hline & $\begin{array}{l}941 \\
\cdots)\end{array}$ & & $\begin{array}{l}\text { mpes } \\
\cdots\end{array}$ & & & & & & & 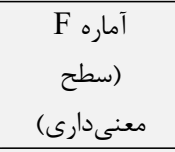 \\
\hline & /V9 & & 194 & & NT & & 194 & & $\Lambda \Delta \varphi$ & 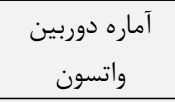 \\
\hline & $=\Delta r$ & & $\Lambda 1 v$ & & $v \Delta S$ & & Gif & & \&बा & (ضريب تعيين) \\
\hline
\end{tabular}


بر همين اساس فرضيات فرعى مربوط به فرضيه دوم يروهش در رابطه با متغير مستقل عملكرد

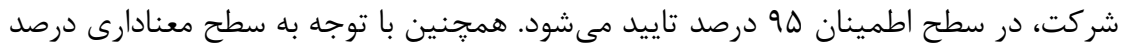

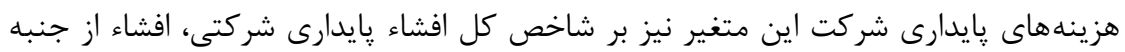

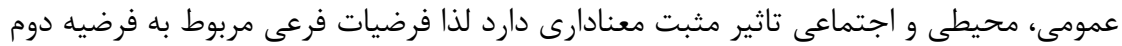

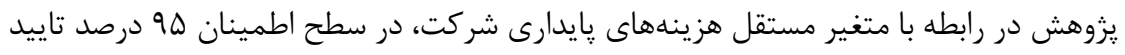

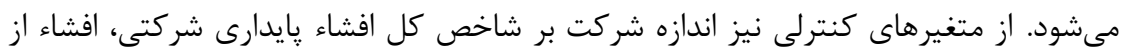

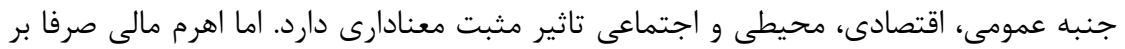

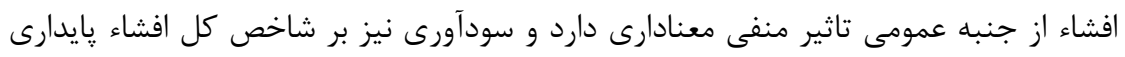

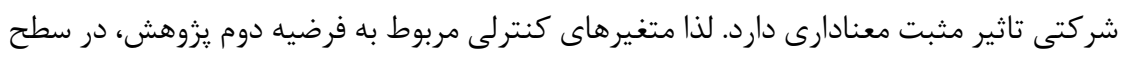
اطمينان ه9 درصد تاييد مى كردد. در جدول شماره (N) آزمون همخطى ميان متغيرهاى تحقيق

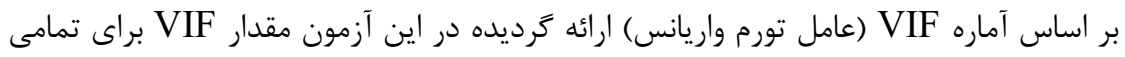

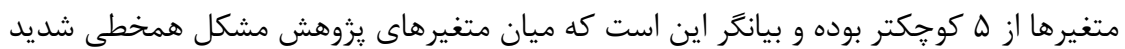

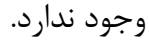

جدول 1: نتايج آماره VIF براى مدل هاى فرضيه سوم

\begin{tabular}{|c|c|c|c|c|c|}
\hline 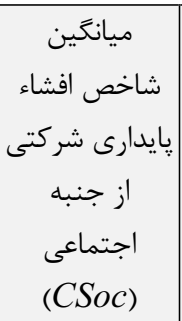 & ميانكين شاخص & شيانَّين شاخص & 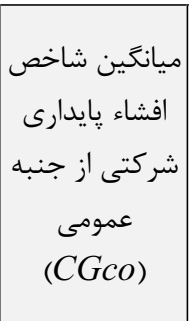 & |فاخص كل شياء & 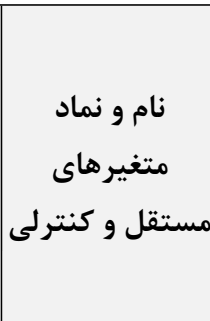 \\
\hline $1 / 499$ & $1 / \pi 49$ & $1 / 791$ & 1/rद9 & $1 / 491$ & $\begin{array}{c}\text { مالكيت دولتى } \\
\text { (GOWN }\end{array}$ \\
\hline $1 / K T T$ & $|/ \pi r|$ & 1/rrT & $|/ \pi r|$ & 1/TrT & $\begin{array}{l}\text { هالكيت اعضاى } \\
\text { هياتهده } \\
\text { (LOWN) }\end{array}$ \\
\hline $1 / \cdot 11$ & $1 / \cdot v 9$ & $1 / 1 r$ & $1 / \cdot v 9$ & $1 / A T$ & $\begin{array}{c}\text { اندازه شركت } \\
\text { (SIZE) }\end{array}$ \\
\hline $1 / \cdot F r$ & $1 / r \Delta$ & $1 / \cdot \Delta \Lambda$ & $1 / r \Delta$ & $1 / \cdot \Delta 1$ & اهرم مالى (LEV) \\
\hline- & - & $1 / \cdot \Delta F$ & - & $1 / \cdot \Delta F$ & نقدينكى (LIQ) \\
\hline $1 / \cdot 14$ & - & I/TV & - & $1 / \cdot T V$ & $\begin{array}{l}\text { سودآورى } \\
\text { (Profit) }\end{array}$ \\
\hline
\end{tabular}



دكتر جهانشاد و همكاران، ارائه الكَويى براى افشاء اطلاعات يايدارى شركتى و ارزيابى اثرعوامل ...

نهايتا نتايج آزمون برآورد مدلهاى فرضيه سوم به شرح جدول (9) مىباشد: جدول 9: نتايج بر آورد مدلهاى فرضيه سوم

\begin{tabular}{|c|c|c|c|c|c|c|c|c|c|c|}
\hline \multicolumn{2}{|c|}{ 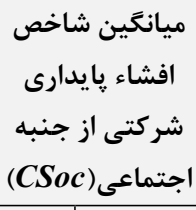 } & \multicolumn{2}{|c|}{ | ميانكَين شاخص } & \multicolumn{2}{|c|}{ 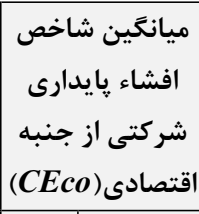 } & \multicolumn{2}{|c|}{ |فشاء بائكين شاخصى } & \multicolumn{2}{|c|}{ ميانكين شاخص } & \multirow{2}{*}{ متنغير و نماد } \\
\hline $\mid$ & ضريب |ركرسيون & | معنى & |رترسيون & | مارى & ضريب & |معنى & ضر سريب & | معنى & رَر سريب & \\
\hline .1 .1$. & .1 .90 & $\mid \cdot \cdot r$ & .1 .11 & $. / . Y \Lambda \mid$ & .1 .19 & $.1 \ldots$ & . & $.1 \%$ & $\cdot \cdot \cdot r \mid$ & \begin{tabular}{|c|} 
دالكيت \\
دولتى \\
$(G O W N)$
\end{tabular} \\
\hline$\cdot \pi \cdot 1$ & $.1 . r F$ & $.1 . .9$ & | & $\cdot 1 \cdot r q$ & .1 .19 & .1 .1$. & .1 .49 & $.1 \cdot 1$. & . $/ \cdot T V$ & \begin{tabular}{|c|} 
هالكيت \\
هضاى \\
المديره \\
(LOWN
\end{tabular} \\
\hline $1 \ldots$ & .1 .94 & $.1 \cdot 4 \lambda$ & $\cdot 1 \cdot \Delta$ & $.1 \cdot r$ & $.1 . .9$ & $.1 \ldots$ &.$|\cdot f|$ & $.1 \ldots$ & $\cdot \cdot r \mid$ & |ندازه شركت \\
\hline . / 94 & $\cdot 1 \cdot \cdot 1$ &.$/ 1 F \Delta$ & -.1 .49 & $.|r| r \mid$ & $.1 . .99$ & $.1 . r \Lambda$ & -.1 .49 & $\cdot 11 \cdot 1$ &.$- / . r \Delta$ & $\begin{array}{l}\text { اهرم مالى } \\
\text { (LEV) }\end{array}$ \\
\hline - & - & - & - & $\cdot \mid \Delta \Lambda$. & $-\cdot 1 \cdot .9$ & - & - & .111. & $-.1 \cdot Y \varepsilon$ & $\begin{array}{l}\text { نقدينكَ) } \\
\text { (LIQ }\end{array}$ \\
\hline .4995 & $-\cdot / \cdot r$ & - & - & $\mid-1490$ & $\cdot / \cdots$ & - & - & .1 .11 & . . r & \begin{tabular}{|l} 
سودآورى \\
(Profit)
\end{tabular} \\
\hline $1 \cdots$ & $-\cdot \cdot / \wedge \vee q$ &. $\mid \Delta Q Y$ & $.1 . \uparrow 9$ & $.1 \cdots$ &.$/ 1 \%$. & $\cdot / \cdots$ &.$- / 14$. & $.1 \cdot 1$ & $-\cdot / \pi q$. & مقدار ثابت \\
\hline & $\begin{array}{l}r / N \| 1 \\
\cdot(\cdots)\end{array}$ & & $\begin{array}{l}|r \wedge| \\
(\cdots)\end{array}$ & & $\begin{array}{l}\cdot \text {. NG9 } \\
1 \cdots)\end{array}$ & & $\begin{array}{l}1 / 1 \wedge r \\
1 \cdots)\end{array}$ & & $\begin{array}{l}N / \varphi \Delta V \\
(\cdots)\end{array}$ & 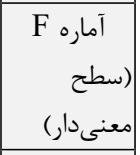 \\
\hline & $1 / v \wedge$. & & 1194 & & ATS & & 促 & & 1119 & |آماره دوربين \\
\hline & - $19 \Delta T$ & & AIV & & NOV & & |GTT & & 1991 & تعيين) \\
\hline
\end{tabular}




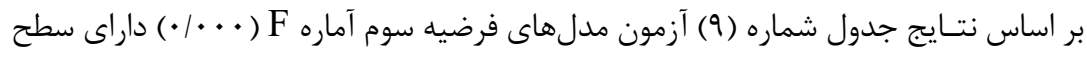

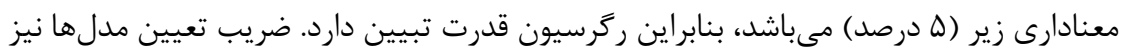

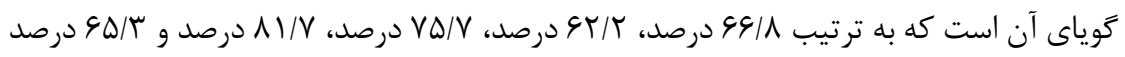

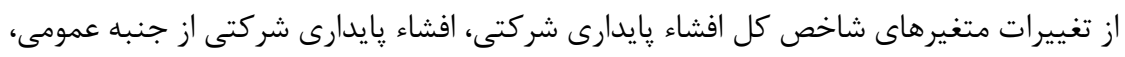

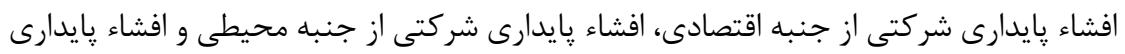

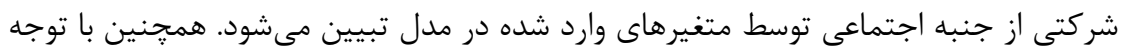

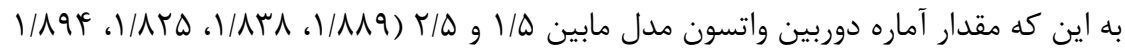

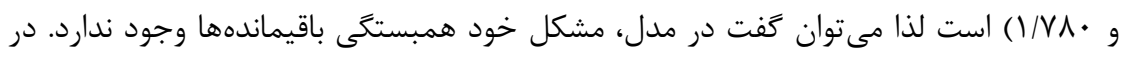

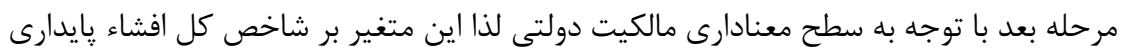

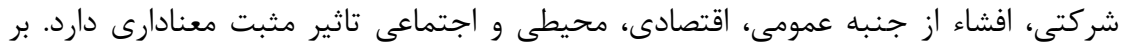

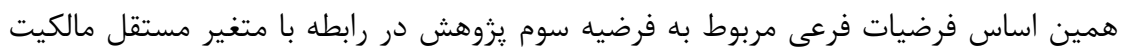

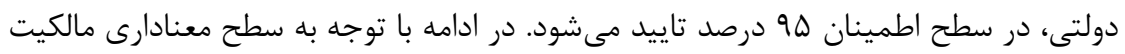

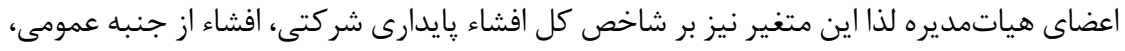

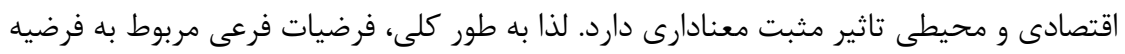

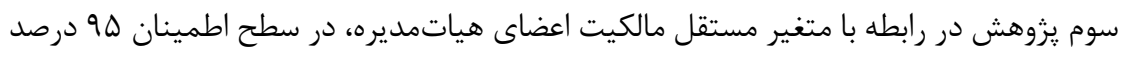

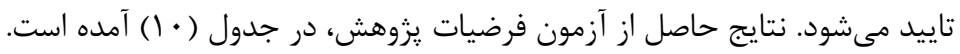

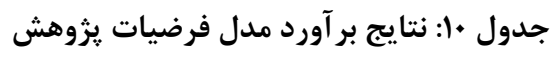

\begin{tabular}{|c|c|c|c|c|}
\hline نتيججه & \multicolumn{3}{|c|}{ فرضيد و متغير هاى آن } & فرضيه \\
\hline تاييد فرضيه & \multicolumn{3}{|c|}{ 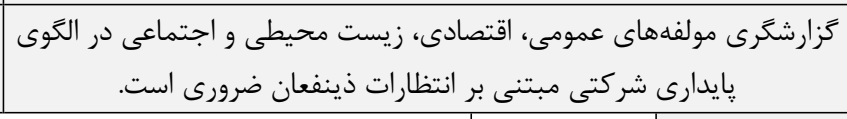 } & اول \\
\hline & نتيجه & متغير مستقل | & \multirow{3}{*}{ 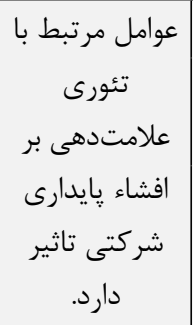 } & \multirow{3}{*}{ دوم } \\
\hline 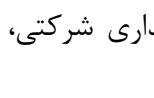 & 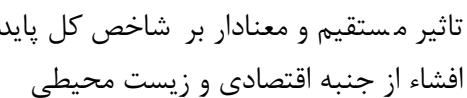 & عملكرد شركت & & \\
\hline \multicolumn{2}{|c|}{ افشاء از جنبه عمومى، زيست و معنادار بر شاخص كل بايدى و اجتماعى شركتى، } & هزي & & \\
\hline \multicolumn{2}{|c|}{ | بايدارى شركتى مستقم و معنادار بر شاخص كل و تمامى جنبههاى } & مالكيت دولتى & 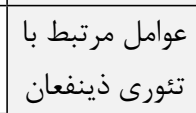 & \\
\hline \multicolumn{2}{|c|}{ 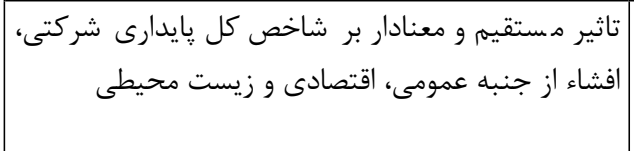 } & مالكيت اعضاى & شركتى تاثير & سوم \\
\hline
\end{tabular}




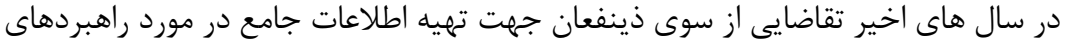

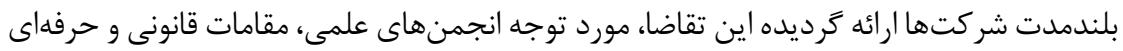

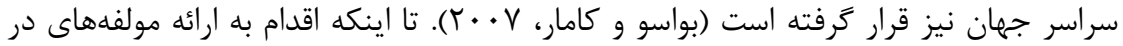

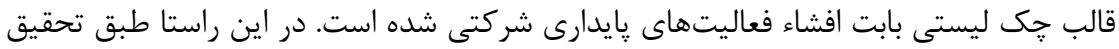

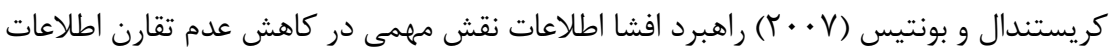
بين مديران و ذينفعان ايفاء مى كند و مى تواند سطح اعتماد آنها را بالا ببرد. در كشور ايران نيز به نظر مىرسد كسترش مالكيت عمومى به عنوان روشى بران براى توزيع عادلانهتر

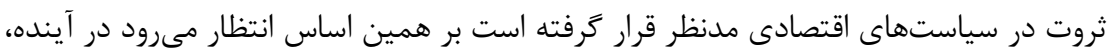

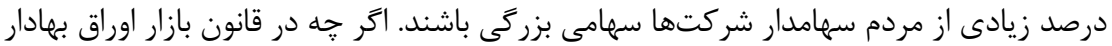

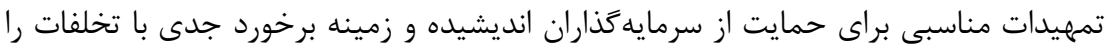

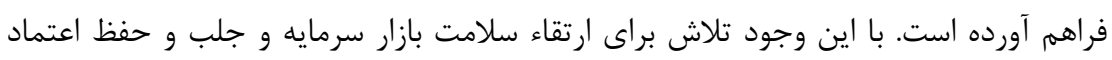

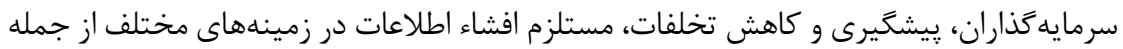
جنبههاى مختلف پايدارى شركتى مىباشد. در همين راستا اين تحقيق اقدام به ارائه الكويى از

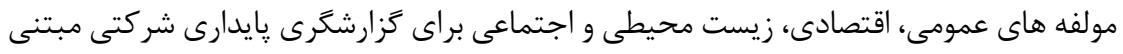

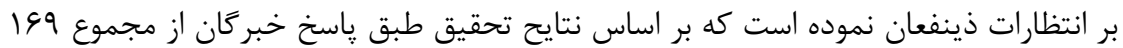
مولفه مورد بررسى، •^م مولفه براى الكوى پايدارى شركتى بسيار ضرورى و ضرورى تشخيص

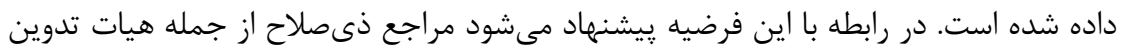

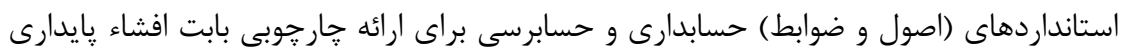
شركتى از نتايج اين تحقيق استفاده نمايند.

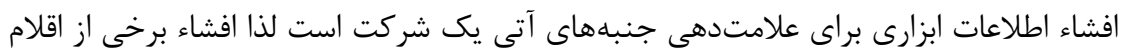

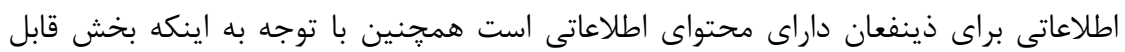

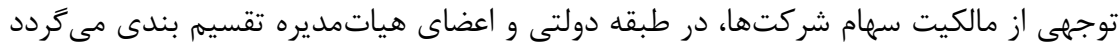

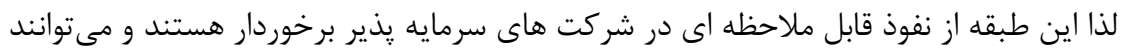

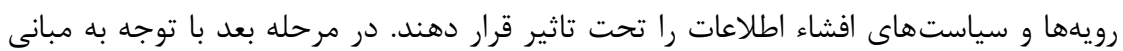

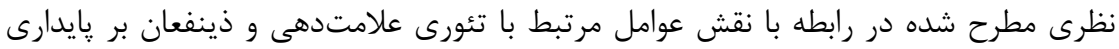

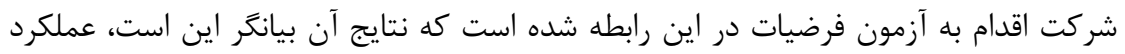
شركت بر شاخص كل افشاء پايدارى شركتى، افشاء از جنبه اقتصادى و محيطى تاثير مثبت معنادارى دارد. همانطور كه انتظار مىرفت افشاى بالاتر از طريق افزايش تقارن اطلاعاتى، ميزان غافلكَيرى (شَفتى) در مورد عملكرد شركت را كاهش مى دهادي و و باعث كاهش نوسان قيمت سهام 
مىشود بر همين اساس طبق تئورى علامتدهى، شركتهايى كه از عملكرد مطلوبى برخوردار

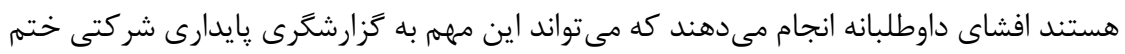

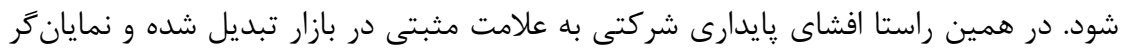

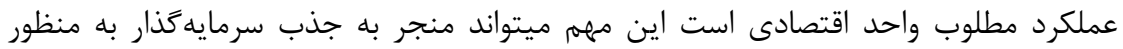

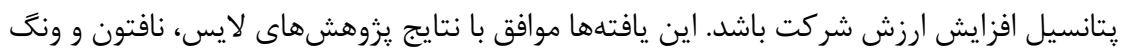

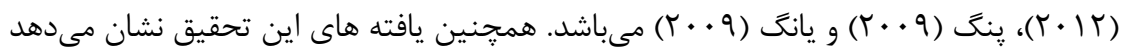

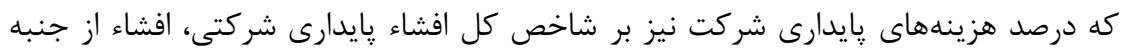

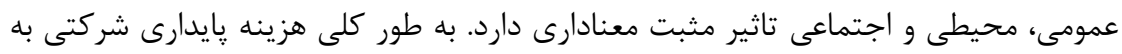

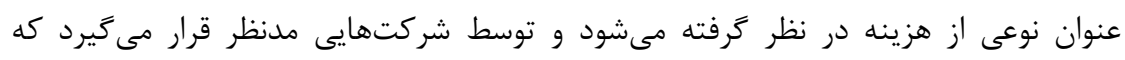

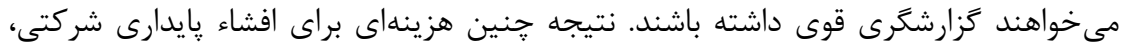

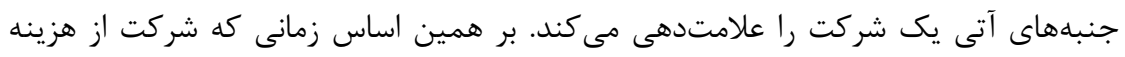

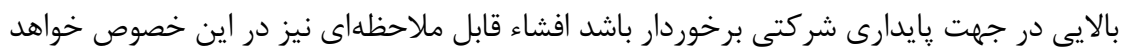

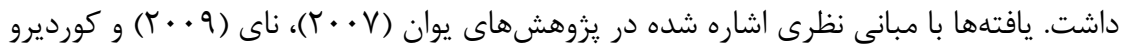

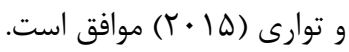

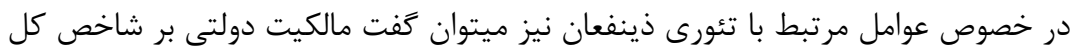

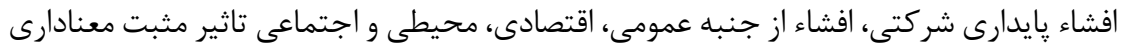

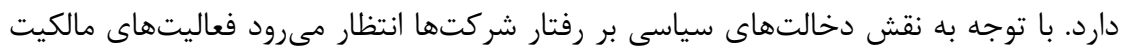

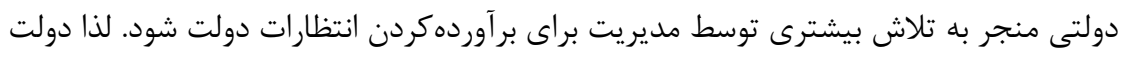

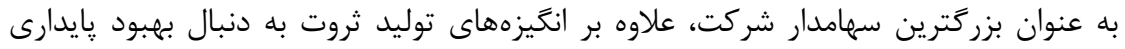

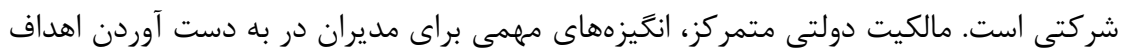

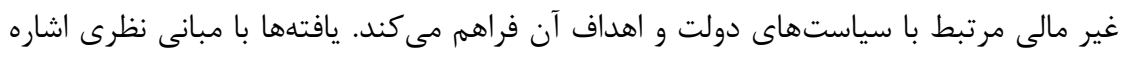

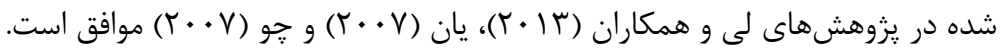

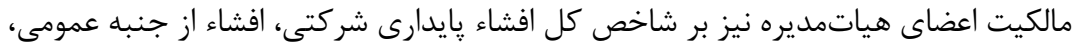

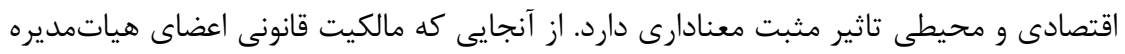

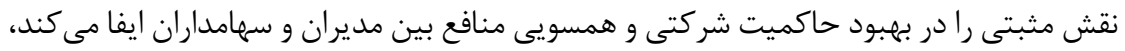

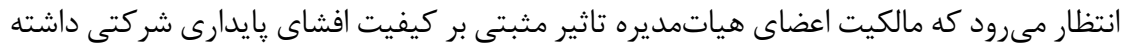

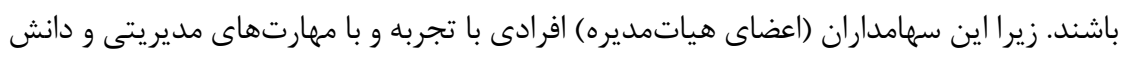

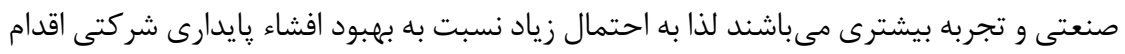

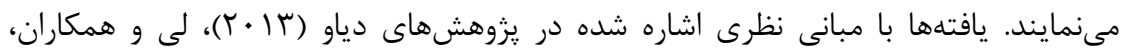

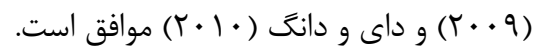


در رابطه با نتايج فرضيات عوامل مرتبط با تئورى علامتدهى و ذينفعان با پِايدارى شركتى

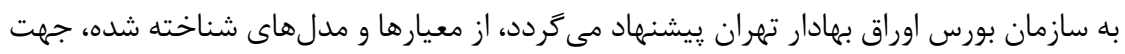

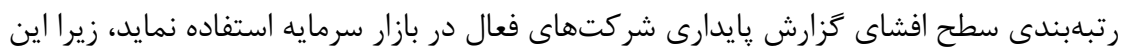

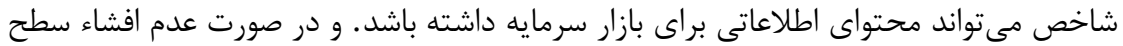

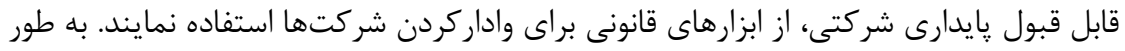

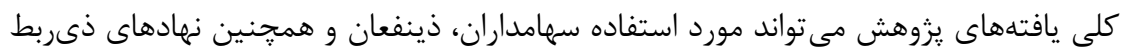

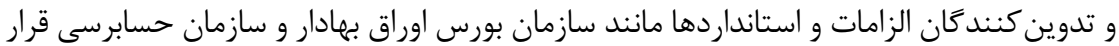

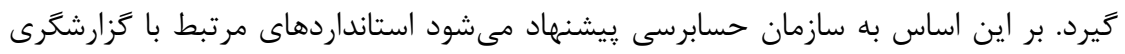
يايدارى شركتها تدوين نمايد.

همجنين بِيشنهاد مىشود سازمان بورس اوراق بهادار از الكوى بدست آمده اين بروهش جهت رتبه بندى سطح افشاى كزارش بايدارى شركتهاى فعال در بازار سرمايه استفاده نمايد، زيرا

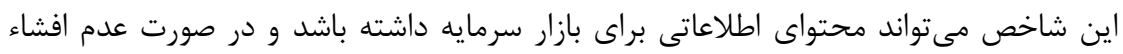

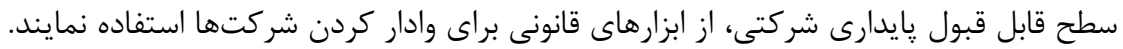

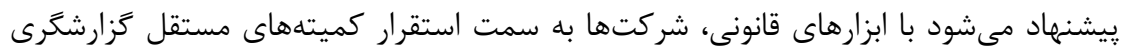

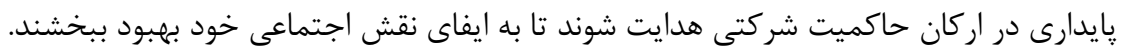

V - Vقدير، تشكر و ملاحظات اخلاقى - V بدينوسيله از تمامى صاحبنظرانى كه در اين تحقيق مشاكرت داشتئند كمال تشات تشكر و قدردانى

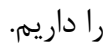

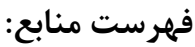

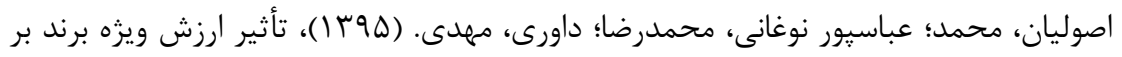

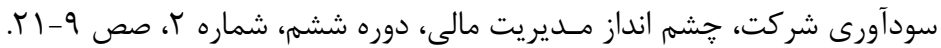

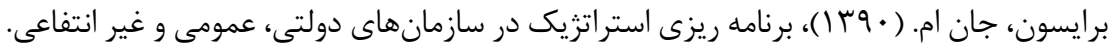

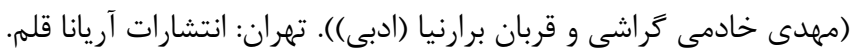

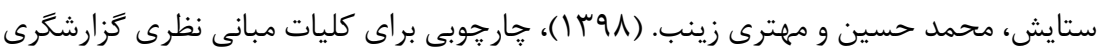
يكيارجه در ايران، مجله يِيشرفت هاى حسابدارى دانشكاه شيراز، دوره يازدهمه، شماره

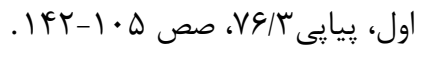


طالب نيا، قدرت الله؛ على خانى، رضيه؛ مران جورى، مهدى. (19 (1)، ارزيابى كميت و ماهيت

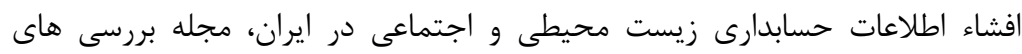

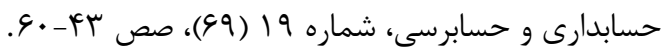

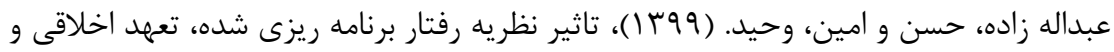

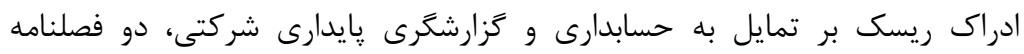

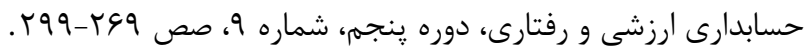

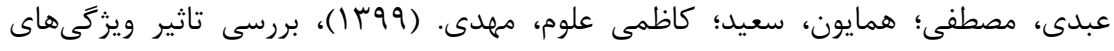

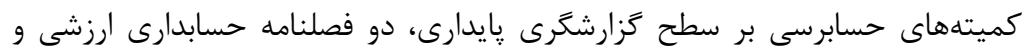

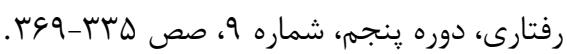

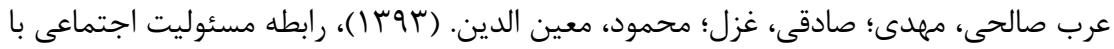

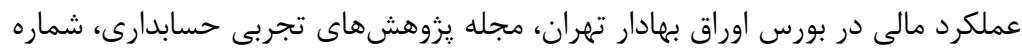

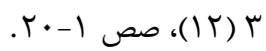

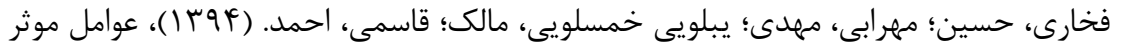

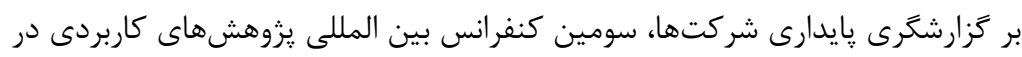

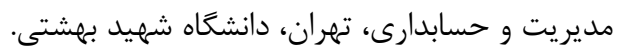

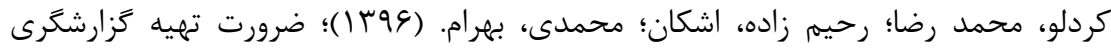

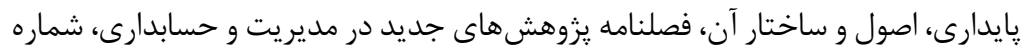

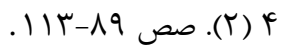
معصومى، سيدرسول؛ صالح نزاد، سيدحسن؛ ذبيحى زرين كلايى، على. (Y) (Y) (I)، شناسايى

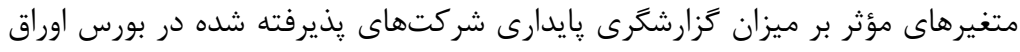

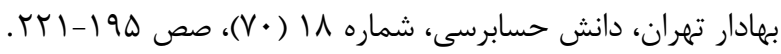

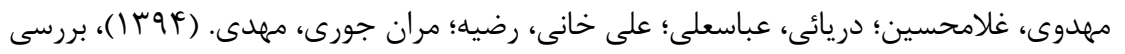

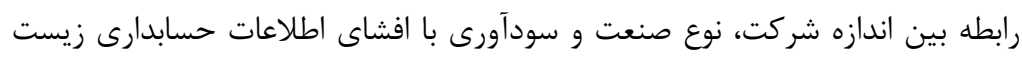

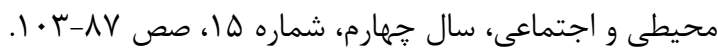

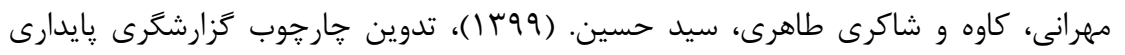

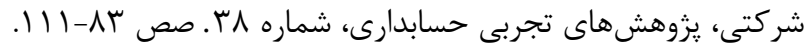

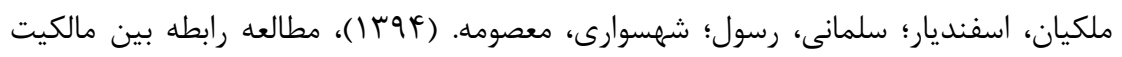

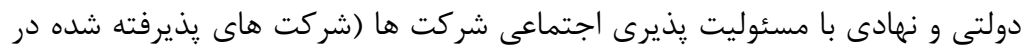

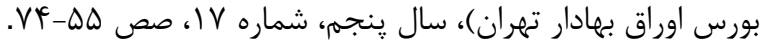



دكتر جهانشاد و همكاران، ارائه الكَويى براى افشاء اطلاعات يايدارى شركتى و ارزيابى اثرعوامل ...

Adekoya A. C., C. S. Oboh, and O. R.Oyewumi. 2020. Accountants perception of the factors influencing auditors' ethical behaviour in Nigeria. Heliyon Journal. 6 (2). 163-172.

Aktas, R., K. Kayalidere, and M. Kargin. 2017. Corporate sustainability reporting and analysis of sustainability reports in turkey. International Journal of Economics and Finance. 5(3): 113-125.

Alvareza, I. G., and E. Ortas. 2017. Corporate environmental sustainability reporting in the context of national cultures. A quantile regression approach, International Business Review. 26 (2): 337-353.

Buallay, A., and J. Al-Ajmi. 2019. The role of audit committee attributes in corporate sustainability reporting. Evidence from banks in the Gulf Cooperation Council. Journal of Applied Accounting Research: 1-17.

Castelo Branco, M. and L, Lima Rodrigues. 2006. Communication of corporate social responsibility by Portuguese banks. a legitimacy theory perspective. Corporate Communications. An International Journal 11 (3): 232-248.

Clarkson, P. M., Y, Li, G.D. Richardson and F.P. Vasvari. 2011. Does it Really Pay to Be Green? Determinants and Consequences of Proactive Environmental Strategies. Journal of Accounting and Public Policy 30 (2): 122-144.

Clarkson, P.M., Y, Li, G.D. Richardson and F.P. Vasvari. 2008. Revisiting the relation between environmental performance and environmental disclosure. an empirical analysis. Accounting Organizations and Society 33(4): 303-327.

Connelly, B. L., S. T. Certo., R. D.Ireland, and C. R.Reutzel. 2011. Doing well by doing good? Implementing new effective integrated CSR strategy. Journal of Management, 37(1): 39-67.

Cordeiro, J. J., and M.Tewari. 2015. Firm characteristics, industry context, and investor reactions to environmental CSD: a Stakeholder Theory approach. Journal of Business Ethics, 130: 833- 849.

Diao, Y. 2013. Min ying Strategy and performance of corporate sustainability in Chinese private sectors (Unpublished doctoral dissertation). Zhe Jiang Industry and Commerce Univisity.

Freeman, R.E. 1984. Strategic Management: A Stakeholder Approach. Pitman, Boston.

Freeman, R.E. 2010. Strategic Management. A Stakeholder Approach. Cambridge University Press, Cambridge.

Frost, G., S. Jones, and P. Lee. 2012. The measurement and reporting of sustainability information within the organization: a case analysis, in Jones, S. and Ratnatunga, J. (Eds.), Contemporary Issues in Sustainability Accounting, Assurance and Reporting. Emerald, Bingley, pp: 197-225. 
Guo, J. L. Sun, and X. Li. 2009. Corporate social responsibility assessment of Chinese corporations. International Journal of Business and Management, 4(4): 54- 57.

Horisch, J., R.E. Freeman and S. Schaltegger. 2014. Applying stakeholder theory in sustainability management. Links, similarities, dissimilarities, and a conceptual framework. Organ. Environ. 27: 328346.

Kaspersen, M., and T. R. Johansen. 2016. Changing social and environmental reporting systems. Journal of Business Ethics, 135: 731-749.

Kleine, A., M. von, and D. Hauff. 2017. Sustainability-driven implementation of corporate social responsibility: application of the integrative sustainability triangle. J. Bus. Ethics 85: 517-533.

Kou, L., C. Yeh, and H. Yu. 2012. Disclosure of corporate social responsibility and environmental management: evidence from China, 19: 273-287.

Kraten, M. 2014. Sustainability The Accounting Perspective. March. THE CPA JOURNAL. pp: $11-14$.

Kwakye, T.O., E. E. Welbeck, G. M. Y. Owusu, and F. K. Anokye. 2018. Determinants of intention to engage in Sustainability Accounting and Reporting (SAR): the perspective of professional accountants. Int $\mathbf{J}$ Corporate Soc Responsibility 3(1): 1-13. DOI:10.1186/s40991-0180035-2.

Li, Q., W. Luo, Y. Wang, and L. Wu. 2013. Firm performance, corporate ownership and corporate social responsibility disclosure in China. Business Ethics: A European Review, 22(2): 159-173.

Lys, T., J. P. Naughton, and C. Wang. 2012. Signalling through corporate accountability reporting. Retrieved from: http://www.kellogg.northwestern. edu/Departments/accounting/ /media/2E9B4390202D448C83EE7A7 504DC298D.ashx

Maas, K., S. Schaltegger, and N. Crutzen. 2016. Integrating corporate sustainability assessment, management accounting, control, and reporting. J. Clean. Prod. 1e12. https://doi.org/ 10.1016/j.jclepro.2016.05.008.

Mori, N. 2010. Roles of Stakeholders in Strategic Decision-Making of Microfinance Organizations. International Business \& Economics Research Journal. 9(7): 516-544

Peng, H. G., 2009. Research on corporate social disclosure in China (Unpublished master's dissertation), Jilin University, Changchun, China.

Prado-Lorenzo, J. M., I. Gallego-Alvarez, and I. M. Garcia-Sanchez. 2009. Stakeholder engagement and corporate social responsibility reporting: 


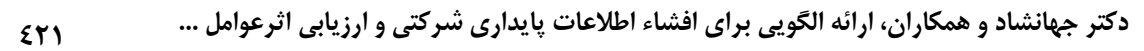

the ownership structureeffect, Corporate Social Responsibility and Environmental Management, 16(2): 94-107.

Qian, C., X. Gao, and A. Tsang. 2015. Corporate philanthropy, ownership type, and financial transparency. Journal of Business Ethics, 130(4): 851-867.

Roosa, S.A. 2010. Sustainable Development Handbook, 2nd ed., The Fairmont Press, GA.

Saleh, M., N. Zulkifli, and R. Muhamad. 2010. Corporate Social Responsibility Disclosure and Its Relation on Institutional Ownership. Managerial Auditing Journal, 25 (0): 591-613.

Tilling, M. V. 2004. Some Thoughts on Legitimacy Theory in Social and Environmental Accounting. Social and Environmental Accountability Journal 24 (2): 3-7.

Weber, M. 2008. The Business Case for Corporate Social Responsibility: A Company- Level Measurement Approach for CSR. European Management Journal 26 (4): 247-61

Yang, J. 2011. Shang shi gong si she hui ze ren bao gao pi lu yin su yan jiu [research on the factors influencing listed compaines' corporate social responsibility report disclosure] (unpublished master's thesis). Southwestern University of Finance and Economics, Cheng Du.

Yuan, Y. 2009. The Research on information disclosure of corporate social responsibility (Unpublished doctoral dissertation), South-western University of Finance and Economics, Cheng Du.

Zhang, J. 2017. Users' perceptions of the drivers for corporate sustainability disclosures made by Chinese listed companies. Retrieved from https://ro.ecu.edu.au/theses/1952. 